ISSN 2587-2001 e-ISSN 2618-6187

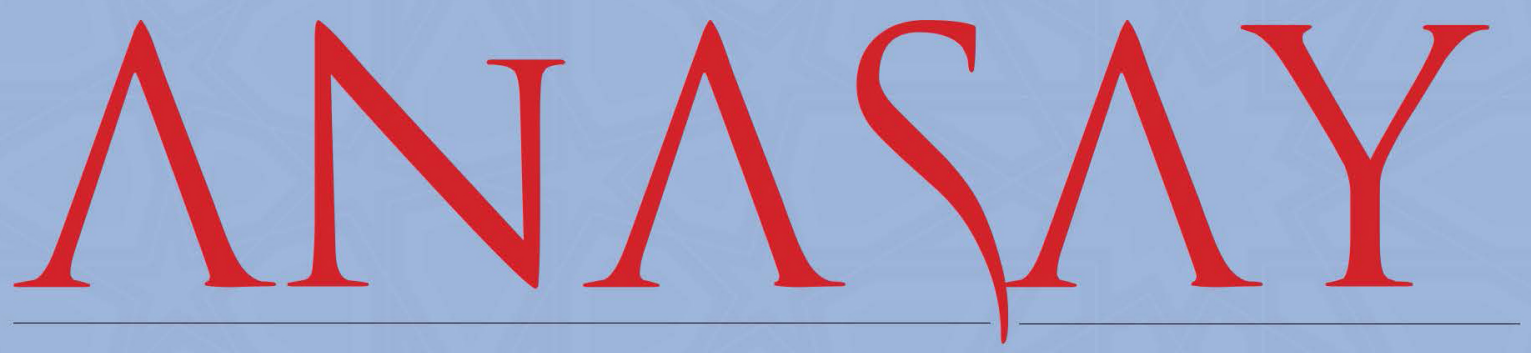

3 Aylık Ulusal Hakemli - Süreli Dergi -Yıl:4 - Sayı:14 - Kasım 2020

\title{
koynunda büyüdük
}

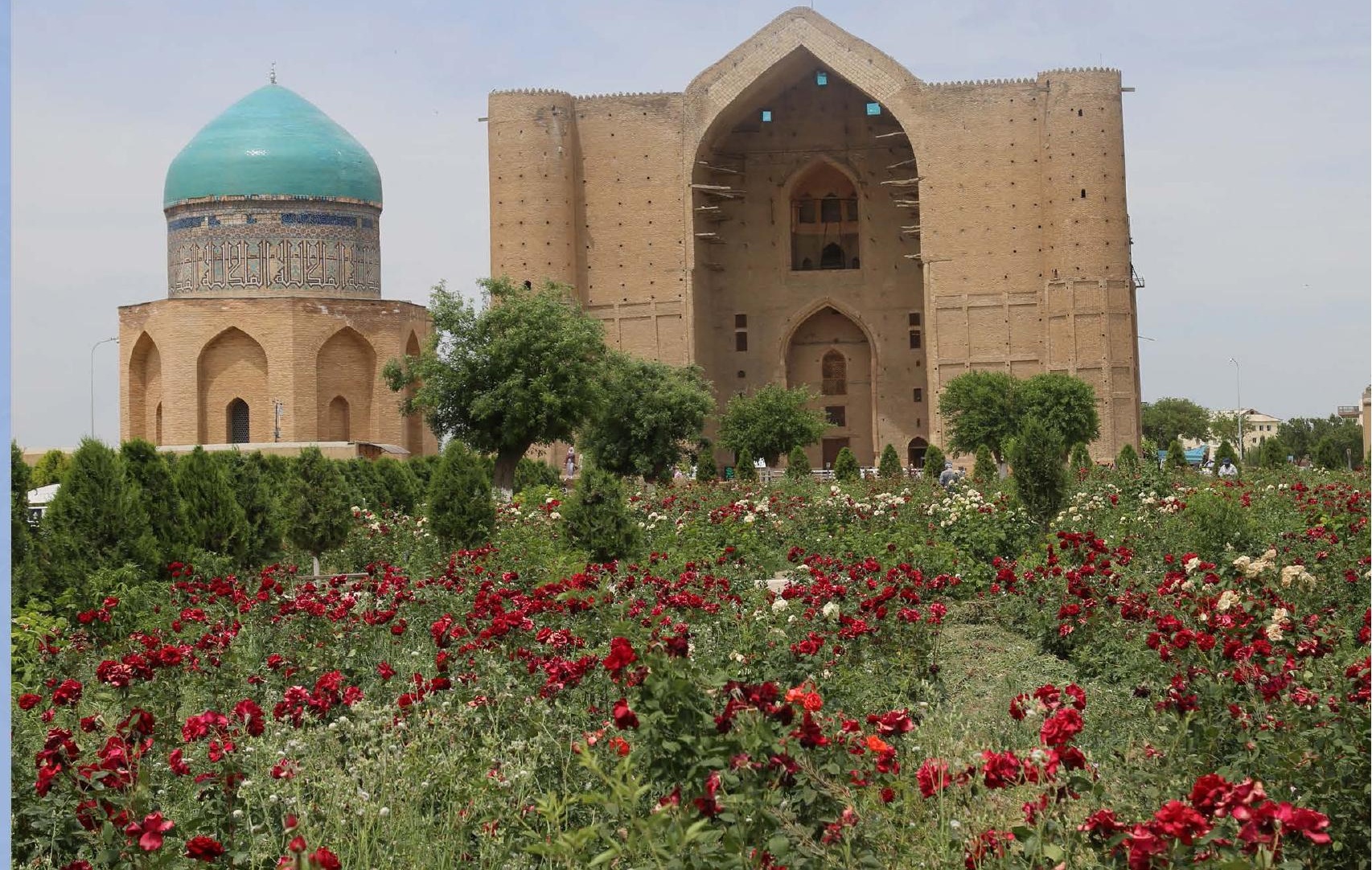




\title{
OYUNLAŞTIRMANIN PAZARLAMADAKİ GÜCÜ THE POWER OF GAMIFICATION IN MARKETING
}

DOI: 10.33404 /anasay.755465

\author{
Çalışma Türü: Araştırma Makalesi / Research Article ${ }^{1}$
}

Erman AKILLIBAŞ* - Kutalmış Emre CEYLAN*

\section{ÖZ}

Oyun, çok eski tarihlerden beri insanların iletişim kurması ve sosyalleşmesi için vazgeçilmez bir olgu olmuştur. Oyunlaştırma, gönüllülük esaslı oluşan amaçları ve hedefleri planlanmış, rekabet unsurunun yer aldığı, kuralları belirlenmiş, bir sistemdir. Oyun tasarımı, pozitif psikoloji, motivasyon teorisi ve davranış ekonomisi disiplinlerinden meydana gelen oyunlaştırma, ticaret, insan kaynakları, eğitim, sağlık, spor ve pazarlama alanlarında etkili bir şekilde uygulanmaktadır. Oyunlaştırma işgörenlerde para benzeri ödüler ile kısa süreli oluşan dişsal motivasyon yerine, ödülün bizzat işin kendisi olduğu gönüllülük esaslı ve sürekliliği olan içsel motivasyon yaratmaktadır. Oyunlaştırma yöntemi işletmelerin işe alım süreçlerini efektif kılan, karar alma becerilerini hızlandıran, sosyalizasyon sürecini kolaylaştıran, öğrenme kabiliyetini geliştiren, odaklanma sorununu gideren, verimliği artıran, hedeflere ulaşmada yol göste-

1- Makale Geliş Tarihi: 20. 06. 2020 Makale Kabül Tarihi: 10. 10. 2020

* Dr. sinopeerman@gmail.com, ORCID ID iD http://orcid.org/0000-0001-8869-8746

* Dr. Öğretim Üyesi, İstanbul Gelişim Üniversitesi Uygulamalı Bilimler Yüksekokulu, İşletme Bilgi Yönetimi Bölümü, emre@kceylan.com, ORCID ID iD http://orcid.org/ 0000-0001-2345-6789 
rici olan, takım ruhunu canlandıran, problemlere etkili çözüm önerileri sunan ve karlılığ 1 artıran etkili bir yöntemdir. Pazarlama sektöründe oyunlaştırma ile işler daha eğlenceli hale gelmekte, hedef kitle ile duygusal bağ kurulmakta, işgörenlerin kendi performanslarını ölçmelerine yardımcı olmakta, hizmet kalitesi artmakta ve müşteri tatmini yaratmaktadır. Bu araştırmada ilk olarak oyun ve oyunlaştırma konularına değinilmiş daha sonra oyunlaştırma ile motivasyon arasındaki ilişki açıklanmış. Oyunlaştırma teorileri ve mekanikleri tanımlanmış. Son olarak da oyuncu tipleri, oyunlaştırma etiği ve oyunlaştırma uygulamalarına yer verilmiştir.

Anahtar Kelimeler: Oyun, Oyunlaştırma, Motivasyon, Oyunlaştırma Teorileri

\section{ABSTRACT}

The game has been an indispensable phenomenon for people to communicate and socialize since ancient times. Gamification is a system of volunteer-based goals and objectives planned, with competitive elements and rules. Consisting of game design, positive psychology, motivational theory and behavioral economics disciplines, gamification is effectively applied in the fields of commerce, human resources, education, health, sports and marketing. In gamification, instead of the short-term extrinsic motivation that can be achieved with rewards such as money, it has created a long-term intrinsic motivation based on volunteering where the reward is the work itself. The gamification method is an effective method that makes the recruitment process of businesses effective, accelerates the decision-making skills, facilitates the socialization process, learning ability, eliminates focus problem, increases efficiency, guides in achieving goals, stimulates team spirit, offers effective solutions to problems and increases profitability. With gamification in the marketing industry, works become more fun, emotional bonds are established with the target audience, it helps employees measure their own performance service quality increases and creates customer satisfaction. Firstly, in this research, the topics of gamification and gamification has been mentioned, and then the relationship between gamification and motivation has been explained. Secondly, gamification theories and mechanics has been defined. Finally, player types, gamification ethics and gamification practices has been included.

Keywords: Game, Gamification, Motivation, Gamification Theories 


\section{Giriş}

"İyi bir oyun kurgusunun oyuncunun kalbindeki motivasyona atılmış bir füze görevi gördüğünü düşünürüm.” Kevin Werbach.

Oyun oynama yeme-içme gibi tüm canlılarda ortak bir davranıştır. İnsanlık tarihinin vazgeçilmez unsurlarından biri olan oyun oynama, tarihsel süreçte birçok araştırmacının ilgisini çekmiş ve bu alanda birçok araştırma yapılmıştır. Günümüzde oyun olgusu işletmelerin hayatta kalabilmeleri için yeni ve yaratıcı yöntemler keşfetmeleri yönünde itici bir güç oluşturmuştur (Özkan 2018: 1). Toplumlardaki sosyal, ekonomik ve teknolojik değişimler oyunların insan hayatındaki yerini ve önemini değiştirmiştir. Yıllar içinde teknolojinin gelişimiyle oynanan oyunlar önce dijitalleşmiş ve daha sonra bilgisayar, tabletler, cep telefonları gibi birçok ortamda oynanabilir hale gelmiştir (Erümit - Karakuş 2015: 396).

Oyunlaştırma konulu çalışmaların büyük bir çoğunluğunun, öğrenme ve eğitim alanında olduğu görülmüştür (Altuntaş - Karaarslan 2016: 434). Oyun, çocuklar için olduğu kadar yetişkinler için de eğlenceli ve öğretici bir olaydır. Tüm dünya nüfusunun $\% 18,75$ 'i her gün dijital bir oyun oynuyor. Türkiyede ise bu oran \%25 seviyelerinde bulunmaktadır (Y1lmaz 2015: 4). Entertainment Software Association (ESA) tarafından Amerika'da yapılan oyun oynama alışkanlıkları konulu araştırma sonuçlarına göre oyun oynayan bireylerin \%25'i 18 yaşın altındaki bireylerden oluşmaktadır. Yetişkinlerden ise \%49'u 18-50 yaş arasında iken \%26'sı 50 yaş ve üzeri bireylerden oluşmaktadır. Oyuncularının \%60'ını erkeklerden, \%40’1 ise kadınlardan oluşmaktadır. Erkek oyuncuların 12, kadınların ise 10 yılı aşkın süredir aktif olarak oyun oynadıklarını ortaya koymuştur. (Gökkaya - Deniz 2014: 61). 2017 y1lında tüm dünyada 1,4 milyar kişinin aktif olarak dijital oyunlar oynadığ 1 bilinmekte ve 2020 yılı sonunda bu sayının 1,6 milyara ulaşacağı öngörülüyor (Gürler 2018: 171). Küresel araştırma şirketi olan Newzoo (2017), dijital dünyada oyunlaştırma verilerine göre 2016 yılında 101 milyar dolar, 2017 yılında ise 108,9 milyar dolar olarak gerçekleşirken kazancın, 2020 yılı sonunda 128,5 milyar doları ulaşması yönündedir (Kunduracıoğlu 2018: 2).

\section{KAVRAMSAL ÇERÇEVE}

\subsection{Oyun}

“Tüm insanlarda oynamayı isteyen bir çocuk gizlidir.” Friedrich Nietzsche 
Oyun kavramının kökeni Yunanca paidia ve ludus kelimelerinden oluşmaktadır. Bu kelimenin gözlenebilen, ifade edilebilen, kuralları olmayan ve davranış odaklı bölümünü paidia (playfulness/playing) ile açıklanırken; niteliksel özelliklere sahip, amaçları, kural ve hedefleri kapsayan kısmı ise ludus kelimesi (gamefulness/gaming) ile ifade edilmektedir (Aydın 2018: 7). Filozof Fredrich Schiller, oyunun insan yaşamı için çok gerekli olduğundan bahsetmektedir (Elkind 2011: 18). Oyun tarih boyunca kültürel bir olgu olarak toplumların yaşayışlarında önemli konumlarda yer almıştır. İnsanın toplumsallaşma sürecinde edindiği misyonla özellikle kültür araştırmacısı ve sosyologların dikkatini çeken bu olgu, aynı zamanda insan davranışını anlamlandırmaya ve açıklamaya çalışan psikoloji bilimi ve oyunun canlılara sağladığı biyolojik faydaları ile fen bilimlerinin de ilgi odağında bulunmaktadır. Arkeolojik buluntular çok eski dönemlerde özellikle Orta Asya'da yaygın olan ve hayvanların aşık kemikleriyle oynanan bir oyunun geçmişinin İ.Ö. 800 yılına kadar uzandığını göstermektedir (Lovett 1901: 280). Aş1k kemiğinin bir oyunda kullanılmış olabileceğini gösteren ilk örnek, Konya Çatalhöyük’te, Neolitik Dönem tabakalarında ortaya çıkarılmıştır. Aşık kemiğiyle oynanan oyunlara, dünyanın hemen her yerinde, neredeyse tüm kültürlerde rastlanır. Bu oyunlar çok sık olmasa da yazılı ve görsel belgelere de yansımıştır (Bozbay 2013: 148-152). Aşık oyunu, tarihi bir Türk oyunu olarak kabul edilir. Oyunu ne zaman, nerede çıktığ tam olarak bilinmemektedir. Çok eski zamanlardan günümüze Türk halklarının yaşadığı coğrafyalarda çocuklar başta olmak üzere her yaş gurubu tarafindan yaygın oynanan kurallı bir oyundur. ${ }^{2}$ Köylü kentli zengin yoksul her insan bulunduğu yerin ve zamanın etkisi altında oyun oynamıştır. Mısır, Roma ve İran'da yapılan kazılarda çok çeşitli oyun eşyaları bulunmuştur. ${ }^{3}$ Eski çağlarda bilindiği üzere en eski oyun araçlarından birisinin, taşlar olduğu ve en eski taş oyununun ise "Beş Taş" olduğu belirtilmektedir (Başal 2007: 246). Antik Misırlılara ait Senet ve Mezo Amerikanlara ait top oyunu mistik ve dini değerler içerirken, Hindistan tarafında doğan "Yılanlar ve Merdivenler" ile ABD'de çıkan ve Hıristiyan ahlakı üzerinden tasarlanmış "Mansion of Happiness" gibi oyunlar manevi etik değerler üzerinde öğretici olmaktadır. Orta Asya'da doğmuş Go ve Shatranj ise stratejik düşünme gibi yetenekleri güçlendirici özelliklere sahiptir. ${ }^{4}$ Ur kraliyet oyunu geçmişi MÖ 3.000 yıllarına kadar uzanan Antik Mezopotamya’ya dayanan bir

2- (https://bilimdili.com/toplum/yasam/karacay-malkar-turklerinde-asik-oyunu/)

3- (https://yilmazturkben07.wordpress.com/cocukta-oyun-gelisimi/oyunun-dogusu-ve-tarihcesi)

4- (http://brandnewgametr.com/Oyunlastirma-Kilavuzu.pdf) 
masa oyunudur. Sümerlerin en eski şehirlerinden biri olan kadim Ur kentinde Leonard Wooley tarafindan 1922 yılında Kraliyet Mezarlarının kazısı esnasında bulunmuştur. Oyun, dört yüzlü zar atılan ve yedi parçasını çeşitli karelerden geçiren iki oyuncu arasındaki bir yarış şeklinde ilerlemektedir. Amaç, her bir parçayı son noktaya taşımaktır. Eğer bir oyuncunun parçası, rakibinin üzerine gelirse ikinci parça en başa geri gönderilir. ${ }^{5}$ M.Ö 5000 yıllarında Antik Mısır'da iki kişi arasında oynanabilen, Senet adı verilen oyuna ait kalıntılara rastlanmıştır. Bu olaylar bize oyunun en eski çağlardan beri hayatımızın içinde yer aldığını göstermektedir (Vardarlıer - İnan 2017: 9). Huizinganın 1938 yılında yayınlanan Homo Ludes kitabında Homo Sapiensin (akıllı insan) ve sonrasında Homo Faberin (imalat yapan/üreten insan) ardından Homo Ludensin (oyun oynayan insan) geldiği açıklamıştır. Oyunun kültürden de önce var olduğuna, hatta insan uygarlığının oyun ile ortaya çıkıp geliştiğini ifade etmektedir. Buna göre, oyunun kültürün taşıyıcılığını yaptığı ileri sürmektedir (Okmeydan 2018: 4751).
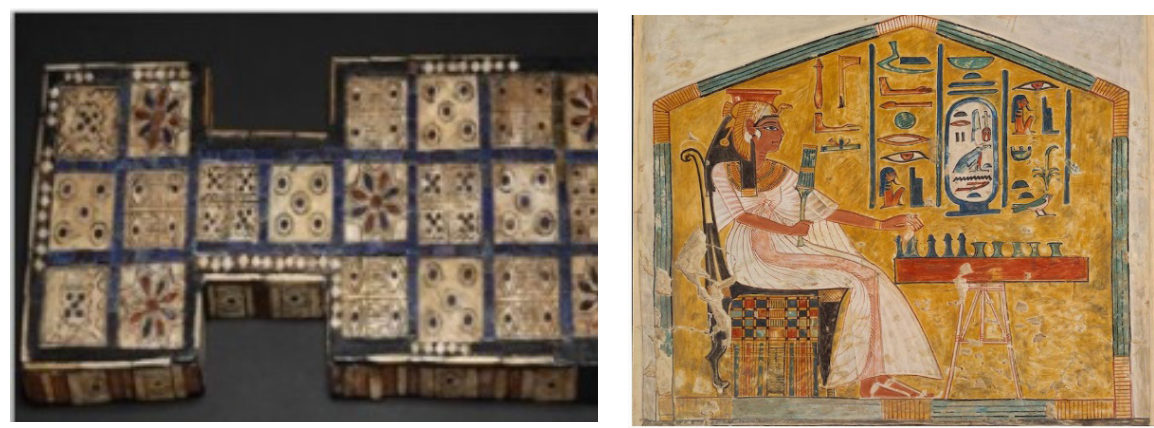

Şekil 1: Ur Kraliyet Oyun Tahtası ${ }^{6}$ Şekil 2: Nefertari Senet Oynarken ${ }^{7}$

“Okullar yokken oyunlar vardl." Aristo Oyun, doğuştan gelen her insanda olan bir güdüdür. İnsan oyun oynadığı sürece insandır. Oyun insana ait olan en önemli eylemdir. Ancak oyun eylemi sadece içgüdüsel veya sadece zihinsel olarak bakmak doğru değildir.

Oyun insanları kendi hayatlarına hazırlamak için gerçekleşen bir öğrenme eylemidir. Oyunların sosyal birliktelik sağlama becerisi de bulunmaktadır. Oyunlar insan özgürlügünün bir ifadesidir. Günlük hayatın akışından farklıdır. Günlük hayatın gereklilik ve ciddiyetinden uzaktır (Sezgin 2016: 2-4).

5- (https://arkeofili.com/ur-kraliyet-oyunu-yeniden-canlandirildi)

6- (https://arkeofili.com/ur-kraliyet-oyunu-yeniden-canlandirildi)

7- (https://tr.wikipedia.org/wiki/Senet_(oyun)\#/media/File:Maler_der_Grabkammer_der_Nefertari_003. jpg 
Kültür araştırmacısı Huizingaya göre oyun, "özgürce razı olunan, ama tamamen emredici kurallara uygun olarak belirli zaman ve mekân sınırları içinde gerçekleştirilen, bizatihi bir amaca sahip olan, bir gerilim ve sevinç duygusu ile alışılmış hayattan başka türlü olmak, bilincinin eşlik ettiği iradi bir eylem ve faaliyettir" (Huizinga 2015: 50). Geç Hitit Dönemi krallıklarından biri olan Karkamış da (Gaziantep) ortaya çıkarılan bir duvar kabartması, aşık oyununa dair bilinen en eski veriyi sunar. Şehrin krallarından biri olan Kamanis ve kardeşlerini gösteren, MÖ 8. yüzyıla tarihlenen kabartmanın sol alt köşesinde iki kişi yere çömelmiş, aralarındaki sehpa veya tabure benzeri bir eşyanın üzerinde, karşılıklı folklor/edebiyat aşık oynarken gösterilmiştir (Bozbay 2013: 148).

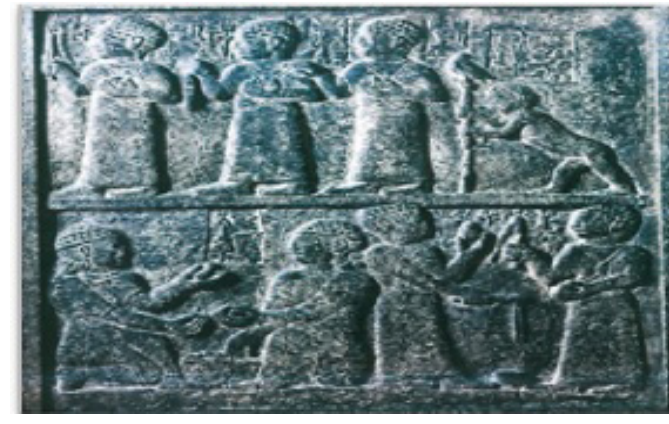

Şekil 3: Karkamış Kabartması (Bozbay, 2013: 149)

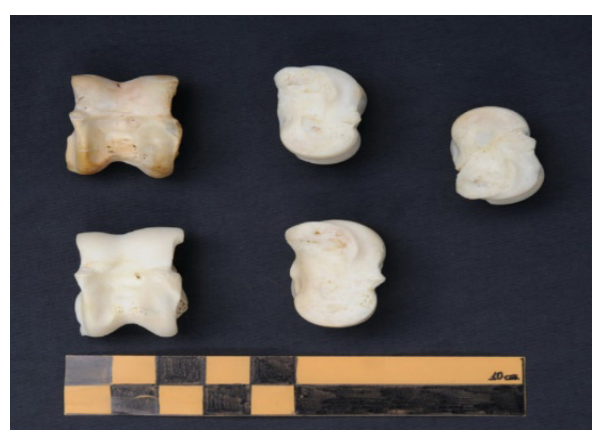

Şekil 4: Aşık Kemiği

(Dandoy, 1996: 51)

Literatürde, oyunun tanımı hakkında net bir uzlaşma bulunmakla birlikte bileşenlerinde genel bir görüş vardır. Bu bileşenler; oyun, çocuk içindir. $\mathrm{Bu}$ yargıyı oyunu indirgeyici bir bakış almaktan ziyade insanın bir gelişim evresi olan çocukluk döneminin destekleyicisi olarak ele almak gerekmektedir. Oyun, kullanıldığı disiplin itibarıyla bir araçtır. Eğitim söz konusu olduğunda oyun, bir öğretim tekniği olabileceği gibi psikiyatri söz konusu olduğunda bir sağaltım aracı olabilmektedir. Dolayısıyla her oyun, gerçek hayatın tıpkısı olmasa dahi provası yahut değerlendirmesi niteliğindedir. Oyun, bir eylem olarak yaratıc1lığın dişa vurumudur (Aytaş - Uysal 2017: 687). Oyun, kuralları belirlenmiş kapalı bir sistemdir. İnsanların sosyalleşmesi, eğlenmesi, güzel vakit geçirmesi, iletişim kurması ve öğrenmesi gibi amaçlarla, belli hedefleri ve kazanma ile kaybetme gibi sonuçları olan bir süreçtir. Oyun, eğlendirici ve bazen de öğretici faaliyetleri kapsar (Vardarlier - İnan 2017: 9). John Dewey oyunu; sonuç gözetilmeyen bilinçsiz davranışlar olarak nitelerken Patrick; özgürce ve kendiliğinden yapılan faaliyetler olarak tanımlamıştır (Ergün 1980: 102). Hemen he- 
men tüm soyut kavramlar (adalet, güzellik, hakikat, zihin) belli bir ölçüde inkâr edilebilirken oyun inkâr edilemeyecek soyut bir kavramdır. İlkel toplulukların kutsal ayinleri, adak törenleri, basit oyunlar biçiminde gerçekleşmektedir. Psikolojik ve fizyolojik açıdan oyun yaşam enerjisi fazlalığından kurtulma, taklit eğilimi, ciddi faaliyetlere hazırlık, egemenlik kurma arzusu, yarışma ihtiyacının giderilmesi, zararlı eğilimlerden kurtulma yoludur. Oyun keyfe kederdir, her an iptal edilebilir. Oyun boş zaman içinde gerçekleştirilen bir aktivitedir. Oyunun kendine ait geçici bir faaliyet alanı vardır, gündelik hayattan bir süre kopma ve rahatlama meşguliyeti olarak görülebilir. Her oyunun istisnasız olarak kuralı vardır ve bu kurallardan kuşku duymak mümkün değildir. Oyun gerçek hayatta karşıllı̆ 1 olmayan bir olay için mücadeledir. Her oyun her şeyden önce gönüllü bir eylemdir. Emire bağlı bir oyun, oyun olmaktan çıkar (Sakallığlu, Erol - Akgün 2014: 118-119). Çoğu insan genç yaşta oyun oynamayı öğrenmeye meyilli başlar ve insan beyni oyun oynamak için inşa edilmiştir. Oyun, çalışanların üretken olabileceği ve iyi vakit geçirebilecekleri sanal bir dünya yaratır. Beyindeki bazı fonksiyonlar organik olarak mantıksal problem çözme yönünde çalışır. Oyun bu doğal süreci alır ve eğlenceli ve ödüllendirici hale getirir (Cook 2013: 49).

Oyun, iki veya daha fazla katılımcıların belirli bir amaca yönelik olarak hedeflenmiş yapıdaki kaynakları yönetmek adına kuralları olan, kararlar verdikleri sanatsal bir üründür (Segin 2016: 3-4) Oyun hakkında en kapsamlı görüş kendi başına kapalı ve kuralları belirlenmiş bir sistemde insanların eğlenmesi, sosyalleşmesi ve öğrenmesi gibi amaçları belli hedefleri ve kazanma ile kaybetme sonuçları olan bir uygulamadır (Yılmaz 2015: 27). Oyun konusundaki en eski kaynaklardan biri olan 10. Alfonso'nun Book of Games (Oyunlar Kitabı) adlı eserinde oyun hakkındaki açıklaması şöyledir. "Tanrı'nın buyruğu, insan doğası gereği her türlü mutluluğa sahip olmayı istediği için yeri geldiğinde actyı ve sıkıntıyı da çekmelidir. Bu yüzden insanlar mutlak mutluluğa sahip olabileceği şeyleri aramak için birçok yol aradılar. Bu arayışın sonucunda insanlar, kendilerine keyif verecek oyunlar keşfettiler.” (Kunduracıŏ̆lu 2018: 8).

\subsection{Oyunlaştırma}

"Yaşlandı̆̆ımız için oyun oynamayı bırakmayız, oyun oynamayı bıraktığlmız için yaşlanırız. ” George B. Shaw.

Oyunlaştırma dünyasında "game" ve "play" kelimeleri birbirlerinden farklı iki anlam taşımaktadır. "Play" kesin kurallara ve bir hedefe sahip olun- 
madan, güzel vakit geçirmek, eğlenmek için yapılan eylem olarak açıklanırken, "Game" kelimesi play'e göre daha ciddi bir anlam taşıyan, kurallara uyarak bir amaca ulaşmak için sonuç elde edilmeye çalışılan oyun şeklidir. ${ }^{8}$ Oyunlaştırma, motivasyon, öğrenmeye teşvik etme, problem çözme, insanlarla iletişim kurma gibi durumlarda etkili olmaktadır (Güler 2015: 87). Oyunlaştırma, oyun tasarım unsurlarının oyun bağlamı dışındaki durumlarda kullanılmasıdır (Niels van der Linden vd, 2018: 171). Oyun elementleri oyunun oluşmasını sağlayan birer yap1 taşıdır. Oyunlarda en sık karşılaşılan oyun öğeleri puan, rozet, liderlik tablosu, ilerleme çubuğu, seviye, avatar, görevler ve hikâyelerdir. Oyun tasarımı ise oyunun fikir aşamasından son kullanıcıya ulaşıncaya kadar geçirdiği evrelerdir. $\mathrm{Bu}$ evreler fikir bulma, fikir olgunlaştırma, senaryo yazımı, karakter tasarımı, oyuncu serüvenini kurgulama, ödül sistemini kurma, oyunun kurallarını belirleme, zorlukları seviyelendirme, görsel tasarımı yapma, ses tasarımını yapma, müziklere karar verme veya müzikleri besteleme, prototip yapma, test etme gibi pek çok evreyi kapsamaktadır. ${ }^{9}$ Oyunlaştırmanın son yıllarda artan popülaritesinin altında yatan en önemli etken oyun ile teknolojinin muazzam harmonisi ve neticesinde büyüyen oyun pazarı ile birlikte belirli amaçlar gözeterek kurgulanan oyunlara artan ilgidir (Altuntaş - Karaarslan, 2016: 435). Oyunlaştırma ifadesi ilk olarak 2008 yılında kullanılmasına rağmen 2010 yılına kadar fazla dikkat çekmemiştir. Günümüzde oyunlaştırma kavramı yerine, productivity games, surveillance entertainment, funware, playful design, behavioral games, game layer, applied gaming kelimeleri yaygın olarak kullanılmaktadır (Deterding, Dixon Khaled - Nacke, 2011: 9). Oyunun temel amacı eğlenceyken, oyunlaştırmanın amacı insan davranışlarını ve eğilimlerini yönlendirmektir (Bahçeci - Uşengül 2018: 707). Oyunlaştırmanın gelişimini mobil uygulamalar, bulut veri programları, Web 2.0, sanal gerçeklik, arttırılmış gerçeklik ve hologram gibi bazı teknolojiler etkilemektedir. 2030 yılına kadar dünya nüfusunun yar1sının çevrimiçi ve mobil teknolojiler oluşturacağı bilinmektedir (Nerguşa vd., 2015: 1112).

Oyunlaştırma, oyun deneyimini ve daha fazla davranışsal çıktıları elde etmek amacıyla motivasyon sağlayıcılığı artırma süreci olarak tanımlanmaktadır (Şahin -Samur 2017: 11). Diğer bir tanıma göre oyunlaştırma psikoloji ve oyun elementlerini tutum değiştirmede başarılı bir şekilde kullanmasıdır (Procopie, Bumbac - Giusca, Vasilcovschi 2015: 1143). Oyunlaştırma kelimesinin isim ba-

8- (https://brandnewgametr.com/game-ve-play-arasindaki-fark/)

9- (http://brandnewgametr.com/Oyunlastirma-Kilavuzu.pdf) 
bası Gabe Zicherman tarafından 2010 yılında düzenlenen ilk Gamification konferansında konuşmasında. 'Oyunlaştırmanın \%75'i psikolojik \%25'ide yeni teknolojilerdir" şeklinde ifade etmiştir (Yılmaz 2015: 27-31). Oyunlaştırma yöntemleri, insanların sosyalleşme, öğrenme, uzmanlaşma, rekabet etme, başarma, statü sahibi olma, kendini ifade etme, fedakârlık yapma isteklerini güçlendirmeyi amaçlar (Mihelaç vd., 2017: 11). Oyunlaştırma bir projeden ziyade bir yöntem ve yaklaşım biçimidir. Oyunlaştırma, projelerin geliştirilmesinde uygulanacak metotları oyuncu tasarım modeli ile belirlemektedir (Bical, 2016: 24).

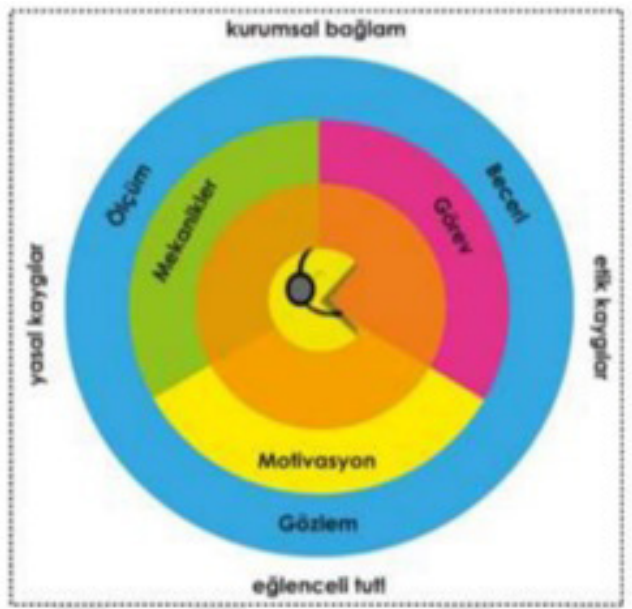

Şekil 5: Oyuncu Merkezli Tasarım (Kumar - Herger, 2013: 29).

Oyunlaştırma tekniği insanların mutlu olmasını sağlayan norepinephrine ${ }^{10}$ ve epinephrine ${ }^{11}$ gibi kimyasal maddelerin salgılanmasını sağlamaktadır. Bu sebeple motivasyonlarının artmasına, öğrenme sürecinin çekici ve etkili olmasına yol açtığı bilinmektedir (Niels van der Lınden vd, 2018: 183). Oyun esnasında zihin tam anlamıyla kendini oyuna verdiği zaman beyin "dopamin" adı verilen bir hormon salgılamaktadır. Bu hormon beynin odaklanmasını sağlamakla birlikte yapılan eylemden zevk alınmasını ve maksimum verim sağlamak amacıyla beynin gereken tüm fonksiyonlarını devreye girmesini sağlamaktadır. (Yılmaz 2015: 127) Dopamin, duyguları, hareketleri, zevk ve acı algılarını etkileyen beyin kimyasalıdır. En temel ve bilinen görevi ödül mekanizmasındaki rolü ve motivasyondur. Vücutta doğal olarak üretilen bir nörotransmitterdir. Dopami-

10- Noradrenalin olarak da adlandırılan (Norepinefrin), insan beyninde ve vücudunda hormon olarak işlev gören bir nörotransmiterdir.

11- Adranalin olarak da adlandırılan (Epinefrin), böbreküstü bezlerinin iç kısımları tarafından öz bölgede salgilanan bir hormondur. 
ninin nörotransmitter olarak bu görevi, beyine gelen bilgileri bir sinir hücresinden diğerine aktarmaktır (Üngüren 2015: 209). Dopamin, dikkat, bağımlılık, ödül arama, işe keyif katarak belirlenen hedeflere ulaşabilmek için kalıcı pozitif davranış değişiklikleri sağlamakta, davranışları ayarlamakta ve hormonal düzenlemelerde fizyolojik olarak görev almaktadır (Çelik vd. 2008: 44). Beyinde dopamin salgılanmasının azalması durumunda ise anhedoni (haz yitimi) ortaya çıkmaktadır. Bu durumda bireylerde istek kaybı, hedefe yönelik davranışlarda bozulma ve günlük aktivitelerden zevk alamama durumu ortaya çıkabilmektedir (Üngüren 2015: 209).

Eski Alkol Bağımlılığı ve Tedavisi Ulusal Enstitüsü nöroloji uzmanlarından Brian Knutson, fonksiyonel manyetik rezonans görüntüleme (fMRI) olarak bilinen beyin tarama tekniği ile yaptığı deneyde, sağlıklı gönüllüleri dev bir tarayıcının altına yatırıp beyinlerinin para kazanmak ve kaybetmekle ilgili bir oyuna nasıl tepki verdiği gözlemlendi. Katılımcılar, nakit para kazanma şanslarının olduğunu öğrendiklerinde beyinlerinin nucleus accumbens ${ }^{12}$ adı verilen bölümlerinde dopamin adlı beyin kimyasalında bir hareketlenme yaşanmakta aynı fizyolojik süreçlerin bağımlılık olgusunda da yaşandığı gözlemlendi. Diğer bir ifadeyle, bireylerin beyin fonksiyonları izlendiğinde, onlara maddi ödüller vaat etmekle, nikotin, alkol, vb uyarıcılar vermek arasında bir benzerlik olduğu görülmüştür. Ödüller bir kere verilmeye başladığı zaman bağımlılık yaratmakta. Böyle bir durumda ödül olgusu bireylerde etkili karar verme süreçlerini bozmakta, riskten kaçınmaya dayalı davranışlardan riske atılmaya meyilli davranışlara doğru bir kayma yaşanmaktadır (Pink 2017).

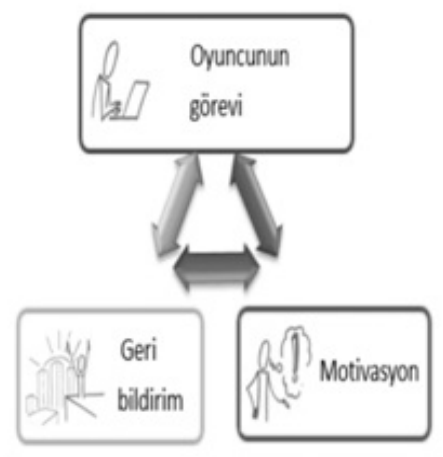

Şekil 6. Bağl1lık Döngüsü (Erümit - Karakuş 2015:405)

12- Temporal lob'un derinlerinde yer alan, bir takım duygusal süreçleri işleyen beyin bölümüdür. Beynin ödül merkezi olarak da bilinir. Zevk, bağımlılık, muhakeme, karar verme ve dürtü denetimi mekanizmaları yönetir. 
Oyun ve oyunlaştırmanın temeli, eğlence unsuruna dayanmaktadır. Oyunlaştırma yöntemi kişilerde daha fazla eğlence, bağlılık ve motivasyon sağlamak için oluşturulmaktadır. Bağlılık döngüsü; oyuncunun neler yapacağı, yapması gerekenleri gerçekleştirmesi için nasıl motive edileceği ve sistemin bu yap1lanlara ne cevap vereceğidir. Oyuncular iyi bir şey yaptığında hızlı bir şekilde geri bildirim alacağını bilmelidir. Ancak hızlı geri dönüt alsa bile oyuncular kazandıkları ödülü de bilmek istemektedir. Bu yüzden eğlenceyi oyunlaştırma sistemine entegre edebilmek çok önemlidir (Erümit - Karakuş 2015: 405).

Oyunlaştırmada madalyonun iki yüzü bulunmaktadır. Birinci yüzü duygulara seslenerek motivasyonu sağlaması nedeni ile davranış değişikliği oluşturması. Bu da çalışan bağlılığı ve mutluluğunu artırmakta. İkinci yüzü ise oyunculara sahada deneyim yaşatarak öğrenme düzeylerini kolaylaştırmasıdır (Vardarlıer - İnan 2017: 14). Oyunlaştırma yapısının en üstünde "Dinamikler", sinırlılıkları bulunan veya zorunlu takaslara "Kısıtlamalar", kullanıcıların rekabet gücünü artıran, merak duygusunu harekete geçiren, "Duygular", hikâyeleştirilmeye girerek devamlılık ve tutarlılık sağlamaya "Öyküleme", oyuncuların gelişimine ve büyümesine olanak sağlayana "İlerleme" ve duyguları harekete geçirerek dostluklar, fedakarlıklar ve bunlar gibi sosyal etkileşim duygusunu geliştirerek etkileşime girmesine "İlişkiler" denmektedir (Özer 2016: 16). Davranışsal ekonomiden türetilen oyunlaştırma sağlık, pazarlama, psikoloji ve tasarım gibi birçok alana nüfuz etmiş durumdadır. Günümüzde oyunlar artık rekreasyon ${ }^{13}$ alanından çıkarak ticaret, eğitim ve üretim alanlarında kullanılır hale gelmiştir (Altuntaş - Kararslan, 2016: 434). Oyunlaştırma aslında yıllardır hayatımızda var olan fakat bizim yeni yeni haberimiz olan bir olgudur (Sever Bical 2018: 218). Gamification kavram1 2002 y1lında İngiliz Bilgi Teknolojileri uzmanı Nick Pelling tarafından ortaya konmuştur (Okmeydan 2018: 4752).

İnsan davranışını ve motivasyonunu etkileyen bu stratejinin katılımcıları, paydaş olabileceği gibi, ürün hizmetlerinden faydalanan müşteri, kişi, taraftar, hasta, seçmen ya da herhangi bir grup olabilmektedir (Altuntaş - Karaarslan 2016: 436). Oyunlaştırma konusu gelecekte iş dünyasının çok daha fazla kullanacağı bir kavram olacaktır. Bugün dev firmalar ardı ardına insan motivasyonunun yakıtı olan oyun kurgularına başvurmaya başlamışlardır (Şahin 2016: 109). Kapp (2012) oyunlaştırmayı; oyunsal düşünme, oyun mekanikleri ve es-

13- Rekreasyon, genel olarak "insanın yaşamını canlandırması, yenilemesi ve boş zamanın değerlendirilmesi etkinliğì" olarak tanımlanır. 
tetik unsurunun birleşimi olarak ifade etmektedir (Kapp 2012: 5). Cunningham (2011) oyunlaştırmayı; kullanıcıların bağlılığını sağlamak ve problem çözmek için oyun düşüncesi ve oyun bileşenlerini kullanma sürecidir (Kocadere - Samur 2016: 402).

Akademisyen ve oyun tasarımcısı Jane McGonigal, en bilinen TED konuşmalarından biri olan "Gaming can make a better world" ("Oyunlar, dünyayı daha iyi bir yer yapabilir”) konuşmasında oyunların bizi daha iyi insanlar yaparak dünyayı değiştirebileceğini öne sürer. McGonigala göre gerçeklik bozuktur ve oyunlar buna çare olabilir. McGonigalın savında oyunlar gönüllü olarak alt etmeye çalıştığımız engeller olarak karşımıza çıkar ve aşmaya gönüllü olmadığımız pek çok engelde insanlık fazlası ile zaman kaybetmektedir. Oyunlar kişiler üzerinde eustress (pozitif stres) olarak adlandırılan bir etki yaratmaktadır. $\mathrm{Bu}$ olay pozitif psikoloji kuramına göre mutluluk veren üretkenlik bu duygudan gelmektedir (McGonigal, 2011). Literatürde çok çeşitli oyunlaştırma bileşeninden söz edilmektedir. Ancak puan, rozet, başarı kayıtları, liderlik sıralaması ve seviye oyunlaştırılmış ortamlarda yaygın olarak tercih edilen bileşenlerdir (Meşe - Dursun 2018: 68).

"İ̧, birinin yapmaya mecbur olduğudur, Oyun ise birinin yapmaya mecbur olmadı̆̆ıdır.” Daniel H. Pink

Oyunlaştırma aslında dünyaya gelip nefes almaya başladığımız andan itibaren hepimiz bu dünyada rolleri ve görevleri olan birer oyuncuya dönüşürüz. Yaşadıklarımız ve yaşantılarımız bizim için tecrübe, tecrübelerimizin tümü ise seviye ve karakterimizi oluşturmaktadır. Yaptığımız her başarısızlıktan bir ders çıkarır, başarılarımızdan da ödüller kazanırız. Gerçekte oyunu kazanmanızın veya kaybetmenizin hiçbir önemi yoktur, önemli olan tek şey oynamaktır. ${ }^{14}$ Oyunlaştırmanın temelinde yer alan, davranış psikolojisi temsilcilerinden olan Stanford Üniversitesi Akademisyenlerinden Profesör Fogg kendi ismini verdiği davranış modelinde 3 noktaya değinmektedir. Bunlar, motivasyon (motivation), aksiyon (ability) ve geribildirim (feedback) olarak açıklanmaktadır. $\mathrm{Bu}$ modelde ilk önce oyuncu motive edilmeli, bu motivasyonla birlikte bir tetikleyici desteğiyle aksiyon aldırılan oyuncuya hemen geribildirim sağlanarak tekrar motive edilmeli ve bu döngü bir düzen içinde çalışmalıdır (Yılmaz 2015: 35). Bir davranışın ortaya çıkması için motivasyon, yetenek ve tetikleyicilerin aynı

14- (https://www.webtures.com.tr/blog/a-dan-z-ye-oyunlastirma) 
anda bulunması gerekmektedir (Şahin - Samur 2017: 5). Bu üç faktör, doğru bir şekilde birleşmezse insanın düşünceleri sadece bir niyet düzeyinde kalır. ${ }^{15}$

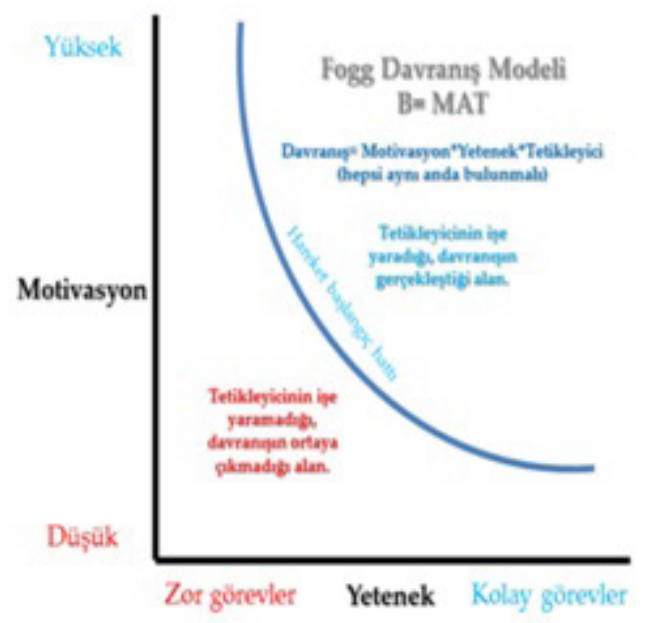

Şekil 7: Fogg Davranış Modeli ${ }^{16}$

Oyunlaştırmaya karar vermeden önce düşünülmesi gereken birkaç nokta bulunmaktadır. Oyunlaştırma davranış değiştirmeye yönelik bir yaklaşım olduğu için kazandırılması ya da pekiştirilmesi hedeflenen davranışın gözlemlenebilen bir davranış olması önemlidir. Oyunlaştırmanın işe yarayıp yaramadığının tespit edilmesi hedeflenen davranışın gözlemlenebilen ve kaydedilebilen bir forma getirilmesi gereklidir (Tunga -İnceoğlu 2016: 271).

Motivasyon konusu psikoloji, yönetim ve pazarlamanın öncelikli konularından biridir. Psikoloji alanında kabul edilen görüşe göre, insan davranışlarının altında ihtiyaçlar ve istekler yatmaktadır. İnsanlar kendi amaçlarına hizmet edecek çabayı göstermeye eğilimlidir (Özdaşl1 - Akman 2012: 74). Motivasyon içsel (intrinsic) ve dışsal (external) olmak üzere ikiye ayrılmaktadır. İçsel motivasyon bireylerin kendilerinden kaynaklanan durumlardır. (Güler - Güler 2015: 126). Kısaca bireyin kendi yeteneklerinin farkında olarak hedeflerine yönelik harekete geçmesidir. İçsel motivasyonda görevin icrası içsel bir ödül sağlamaktadır. Görevin sağladığı keyif, kendi ödülünü yaratmaktadır (Pink 2009). Dışsal motivasyon, davranışın bir sonuç için gerçekleştirildiği motivasyon çeşididir.

15- (https://www.temelaksoy.com/pazarlama-yapmak-davranis-mimarligi-yapmaktir/)

16- (https://www.slideshare.net/ercanaltug/gamex-akar-oyunlastirma-ornekleri) 
Birey bir davranışı, davranıştan ziyade davranışın sonuçları için sergilemektedir. Böylece birey, içsel doyum elde etmek için değil, ödül elde etmek ya da ceza almamak için davranışlar gösterir (Aslan - Doğan, 2020: 292). Bazen çalışanların yapmaktan hoşlandığı bir iş, yönetici tarafından vaat edilen bir ödül için yapıldığında, işgörenin işi yapmaktan dolayı aldığı zevk ve işe olan içsel ilgisi yok olmaktadır. Bu yüzden oldukça kuvvetli olan içsel motivasyonun, bazen bir takım dışsal ödüllerden zarar görme ihtimali bulunmaktadır (Selen 2016: 103). Oyunlaştırmanın en önemli gücü motivasyon üretmesidir. Motivasyon ise bir davranışın başlaması, devam etmesi veya sonlandırılmasından sorumlu olan psikolojik süreçtir. Herhangi bir eylem yapmak için insanları harekete geçiren, yapılan eylemi durdurup farklı bir eyleme yönlendiren olgu motivasyondur. ${ }^{17}$ Dwight D. Eisenhower'in söylediği üzere; motivasyon, insanların onlardan yapmalarını istediğiniz şeyi, siz istediğiniz için değil, kendileri istedikleri için yaptıklarını düşünmelerini sağlamaktır (Yalçın 2016: 31-32).

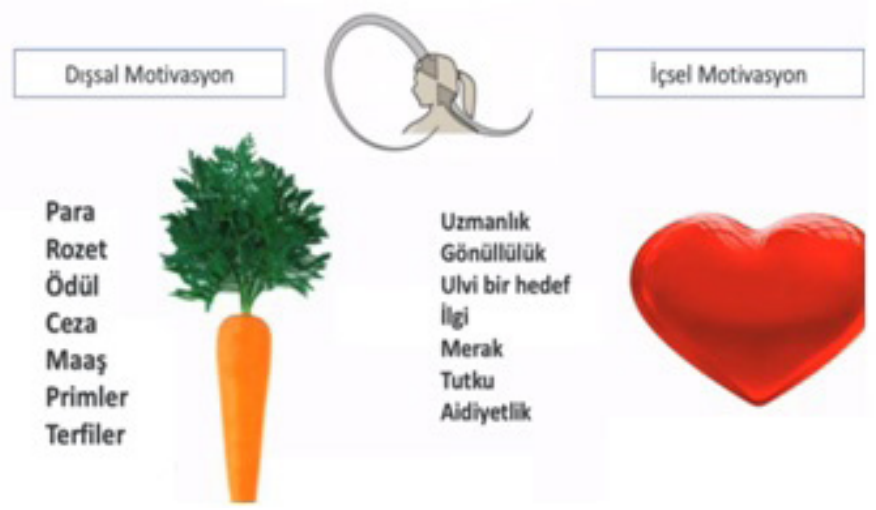

Şekil 8: Öz Belirleme Kuram1 ${ }^{18}$

Amerikalı oyun tasarımcısı Jesse Schell 2010 yılında D.I.C.E.'de yaptığı sunumunda şu ifadelere yer vermiştir; Bir sabah kalkıp dişlerinizi firçaladığınızda diş firçanız size, bravo dişlerini çok iyi firçaladın diyecek ve 10 puan verecek bu sayede ne kadar uzun süre dişlerinizi fırçaladığınızı ölçebilecek. Bir hafta boyunca her gün dişinizi firçaladığınızdaysa size bir bonus puan daha verecek ve aslına bakarsanız buradaki asıl mesele, ne kadar diş firçası eskittiğiniz ve ne kadar diş macunu kullandığınızdır (Bayraktar 2014: 13-14).

17- (http://brandnewgametr.com/Oyunlastirma-Kilavuzu.pdf)

18- (https://www.oyunlastirma.co/makale/turk-sirketlerinin-oyunlastirma-yolculugu) 
Pennsylvania Üniversitesinden Profesör Kevin Warbac tarafından oluşturulan oyunlaştırma takım çantası üç aşamadan oluşmaktadır. Bu aşamalar, dinamikler (dynamics), mekanizmalar (mechanics) ve bileşenler (components) olarak açıklanabilir (Yılmaz 2015: 131).

Oyun elementlerinde dinamikler, kontrol edilmesi gereken, ama oyuna doğrudan tanıtılmayan unsurlardır. Örneğin; hikayeleştirme, ilerleme, kısıtlamalar, duygular, ilişkiler. Mekanikler, faaliyetlere yön veren ve kullanıcıların ilgisini arttıran temel süreçlerdir. Bunlar; mücadele, iş birliği, rekabet, geri bildirim, kaynak edinimi, ödüller, sıra, kazanım durum. Bileşenler ise, oyuncu ile etkileşime giren unsurlardır. Bunlar; kazanımlar, puanlar, rozetler, lider tablosu, seviyeler, takımlar, sanal eşyalar, içeriğe ulaşma, koleksiyonlar, macera, hediye, zorlu mücadeleler, sosyal grafiklerdir (Baiturova - Alagöz 2017:135).

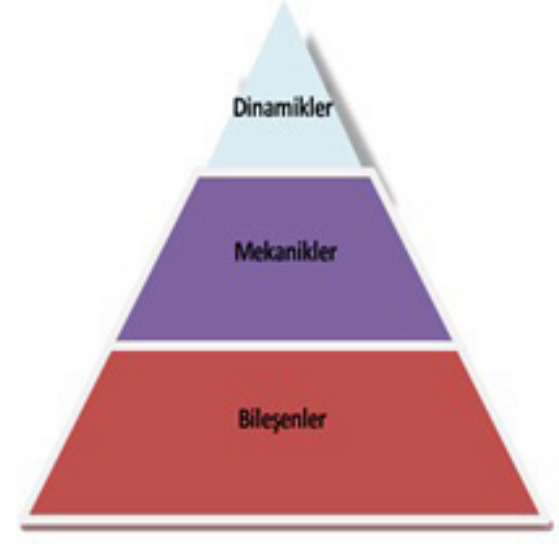

Şekil 9: Oyunlaştırma Bileşenleri (Werbach K. - Hunter D. (2012)

Oyun çantasında dinamikler soyutluk sıralamasına göre en yukarıda olanlar elementlerdir. Bir oyunlaştırma tasarımında dinamikleri oluşturan unsurlar oyunsu deneyim boyunca hissedilen temel yapısal özelliklerden oluşmaktadır (Özkan 2018: 35-36). Mekanikler, oyunu ileriye götüren ve oyuncu katılımını sağlayan temel işlemlerdir. Mekanikler oyunlaştırma deneyimi başlamadan önce de bilinen ve oyuncudan oyuncuya değişmeden sabit olarak bulunan unsurlardır (Robson, Plangger, Kietzman ve McCarthy ve Pitt, 2015: 414). Bileşenler son kullanıcının gördüğü, oyunlaştırılan sürece entegre olmuş, oyuncuyla direkt etkileşime geçen, arkasında birçok programsal mekanik, dinamik bulunduran önyüzdeki tasarımsal objelerdir (Y1lmaz 2015: 142). 
Tablo 1: Oyun Elementleri (Güler 2015:127, Altuntaş - Kararslan 2016:436-438; Güler, 2015:87; Bozkurt - Kumtepe 2014:149)

\begin{tabular}{|c|c|c|}
\hline Dinamikler & Mekanikler & Bileşenler \\
\hline $\begin{array}{l}\text { Duygular: Oyunun içerisinde } \\
\text { heyecan, merak, üzüntü, sevinç } \\
\text { ve kızgınlık gibi farklı duygula- } \\
\text { rın yaşanmasıdır. }\end{array}$ & $\begin{array}{l}\text { Meydan okuma: Çözümü } \\
\text { için çaba gerektiren } \\
\text { bulmaca ya da diğer } \\
\text { görevlerdir. }\end{array}$ & $\begin{array}{l}\text { Puanlar: Puanlar oyuncu- } \\
\text { lar arasında hatta tasarımcı } \\
\text { ile oyuncu arasında paylaşı- } \\
\text { lan önemli bir unsurdur. }\end{array}$ \\
\hline $\begin{array}{l}\text { Kısitlar: Oyunun belirli bir çer- } \\
\text { çevesini oluşturur. }\end{array}$ & $\begin{array}{l}\text { Şans Faktörü: Rastlantısal } \\
\text { unsurlardır. }\end{array}$ & $\begin{array}{l}\text { Rozetler: Oyun süreci içe- } \\
\text { risindeki bazı başarıların } \\
\text { görsel olarak temsilidir }\end{array}$ \\
\hline $\begin{array}{l}\text { Öyküleme: Oyun içerisinde bir } \\
\text { hikâyenin oluşturulmasıdır. }\end{array}$ & $\begin{array}{l}\text { Rekabet: Bir kişi ya da } \\
\text { grubun kazanmak için mü- } \\
\text { cadeleye girişmesidir. }\end{array}$ & $\begin{array}{l}\text { Liderlik Panoları: Oyun- } \\
\text { cuların diğer oyunculara } \\
\text { göre sıralamasını gösteren } \\
\text { tablolar. }\end{array}$ \\
\hline $\begin{array}{l}\text { İlerleme: Oyuncunun büyümesi } \\
\text { ve gelişmesidir. }\end{array}$ & $\begin{array}{l}\text { İş birliği: Bir hedefi ya da } \\
\text { görevi gerçekleştirmek için } \\
\text { oyuncuların birlikte takım } \\
\text { halinde çalışmasıdır. }\end{array}$ & $\begin{array}{l}\text { Kazanımlar: Belirlenmiş } \\
\text { olan hedeflere ulaşılması } \\
\text { halinde oyuncuya verilen } \\
\text { ödüllerdir. }\end{array}$ \\
\hline \multirow[t]{4}{*}{$\begin{array}{l}\text { İlişki: Dostluk, statü ve fedakâr- } \\
\text { lık gibi duyguların ortaya çıkma- } \\
\text { sını sağlayan sosyal etkileşimdir. }\end{array}$} & $\begin{array}{l}\text { Mücadeleler: Çözülmesi } \\
\text { için çaba sarf edilen } \\
\text { bulmaca ya da diğer } \\
\text { görevlerdir. }\end{array}$ & $\begin{array}{l}\text { Avatarlar: Oyuncunun } \\
\text { oyun karakterinin görsel } \\
\text { olarak gösterimidir. }\end{array}$ \\
\hline & $\begin{array}{l}\text { Ödüller: Belirli bir eylemi } \\
\text { ya da başarıyı yerine getir- } \\
\text { mesi durumunda sağlanan } \\
\text { faydadır. }\end{array}$ & $\begin{array}{l}\text { Zorlu Mücadeleler: } \\
\text { Oyunda ilerleyebilmek ya } \\
\text { da oyun içi nadir nesneleri } \\
\text { toplayabilmek için aşılması } \\
\text { gereken ve zor olan müca- } \\
\text { deledir. }\end{array}$ \\
\hline & $\begin{array}{l}\text { Alışveriş: Oyuncular ara- } \\
\text { sında oyun nesnelerinin } \\
\text { ticaretinin yapılmasını } \\
\text { ifade etmektedir. }\end{array}$ & $\begin{array}{l}\text { Sorgulamalar: Hedefler ve } \\
\text { ödüller ile önceden tanım- } \\
\text { lanmış zorluklardır. }\end{array}$ \\
\hline & $\begin{array}{l}\text { Sıra: Oyuncuların sırasıyla } \\
\text { katılımın sağlanmasıdır. }\end{array}$ & $\begin{array}{l}\text { Koleksiyonlar: Rozetleri } \\
\text { ya da oyun içi nesnelerin } \\
\text { toplanmasıdır. }\end{array}$ \\
\hline
\end{tabular}




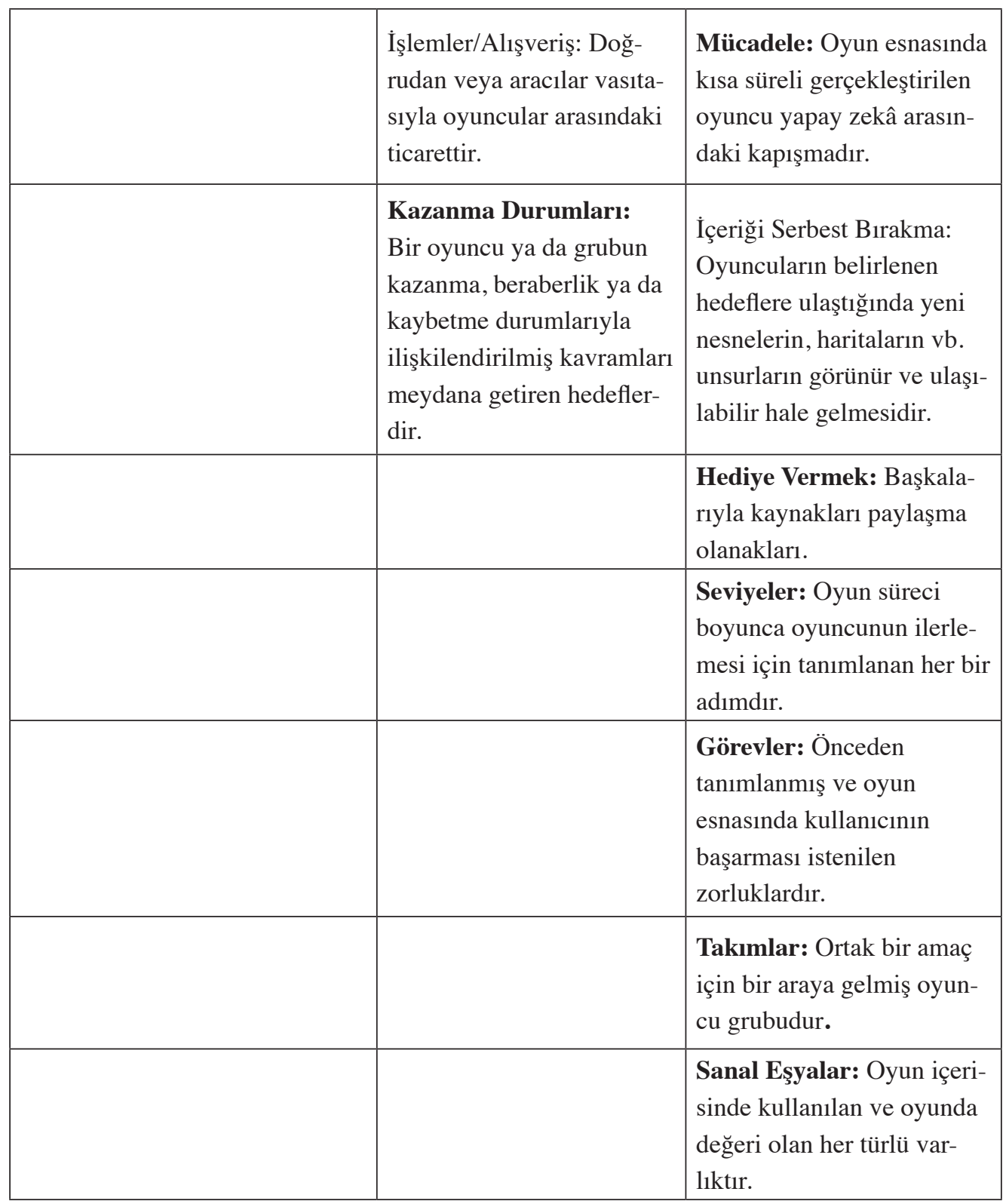

\subsection{Akış Kuramı}

"Önce oyunun kurallarını öğrenmelisiniz sonra da herkesten iyi oynamalisınız.” Albert Einstein

Csikszentmihalyi rekabet ve ödül düzeninin dengeli olmasının insanlarda mutluluk ve motivasyon yarattığını belirtmiştir. Akış kuramına göre oyun oynarken kişisel oyundaki hedefe ulaşabilmek adına motivasyon gösterip de- 
neyim kazanmaktadır. Oyunlardaki temel amaç içsel motivasyon sağlayıp, eğlenceye dönüştürmektir ki bu da akışla mümkün olmaktadır. İçsel motivasyon yaşanmadan akışın yaşanması mümkün değildir (Kunduracıŏglu 2018: 31-32). Csikszentmihalyi araştırmasında, görüştüğü kişilerin yapmış oldukları eylemler birbirinden farklı da olsa (örneğin, dağ tırmanışı, satranç oynama, iş hayatında yapılan görevler, dans etmek) süreç içerisinde kendilerini mutlu hissettikleri anı ve duygu yoğunluğunu tarif etmeleri istendiğinde bu süreci, eyleme tam olarak odaklandıkları, zamanın olduğundan hızlı aktığı ve işi yaparken zevk aldıkları bir süreç şeklinde birbirlerine oldukça benzer biçimde tanımladığını fark etmiştir (Özkara - Özmen 2016: 72). Akış kuramı, dünyanın farklı yerlerinde yaşayan ve birbirinden tamamen farklı iş kollarında çalışan yüzlerce insandan oluşan çok geniş bir örneklem üzerinde yapılan çalışmalar sonucunda oluşmuştur. Resim, müzik, spor, satranç, tıp ve endüstri gibi farklı içerik ve olgulara sahip iş alanlarından kişilerin, işlerinde en verimli ve keyifli bir halde performans gösterdiği süreçler incelenmiştir (Tezdel 2016: 3).

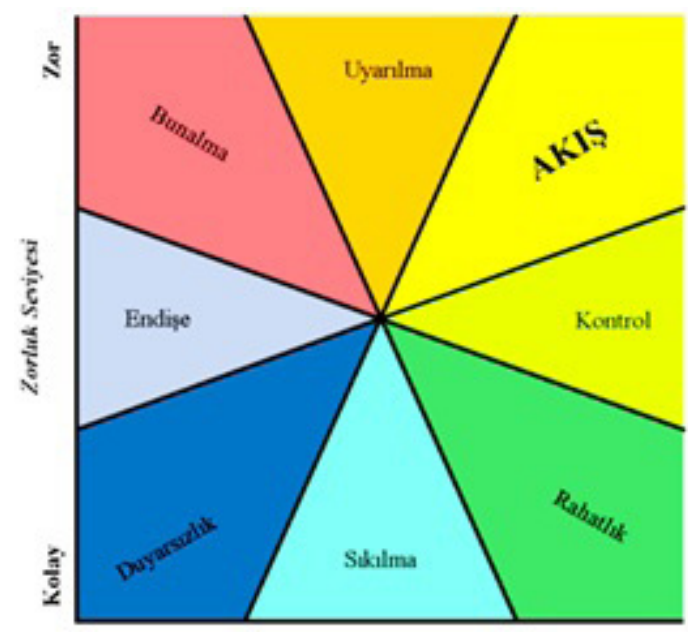

Şekil 10: Akış Kuramı (Kunduracıoğlu 2018:31)

Akış Kuramı, pozitif psikoloji kuramıdır ve Mihaly Csikszentmihalyi tarafından 1975 'te görüşme yapıp, gözlemlediği birçok insandan sonra bulunmuştur. Csikszentmihaly, Akış Kuramını ilk olarak işini tutkuyla yaparken kendini kaybeden sanatçıları görünce fark etmiştir. Özellikle ressamların işlerini büyük bir tutku ile yaparken yemek, su ve uyku gibi en temel ihtiyaçlarını dahi gidermeyi unutup “öz farkındalıklarını” kaybetmesinden etkilenmiştir. Oyuncu 
oyunda ilerledikçe, oyun içi yetenekleri artar. Oyuncunun yeteneklerine göre oyunun zorluk seviyesi de doğru orantılı bir şekilde artmalıdır ki oyuncunun içsel motivasyonu sürekli bir şekilde aktif tutulsun. Zorluk seviyesi, oyun için yetenekler arttıkça artmıyorsa sürekli aynı seviyede kalıyorsa oyuncunun içsel motivasyonu da düşemeye başlar. Oyuncu, yeni kazandığı yetenekleri sayesinde zorlukların üstesinden geldiğinde bir motivasyon kaynağı oluşturmaktadır. (Zicherman - Cunningham 2011: 16). Akış kavramında olan bireyler için zaman hızla geçmekte ve her şeyi unutulmaktadır. Yapılan işten zevk alan ve kendini mutlu hisseden bireyler, iş ile ilgili pozitif yargılara varmakta. Bu zevk veya mutluluk akış deneyiminin duygusal değerlendirilmesini oluşturmaktadır (Yeşiltaş - Türk 2017: 119).

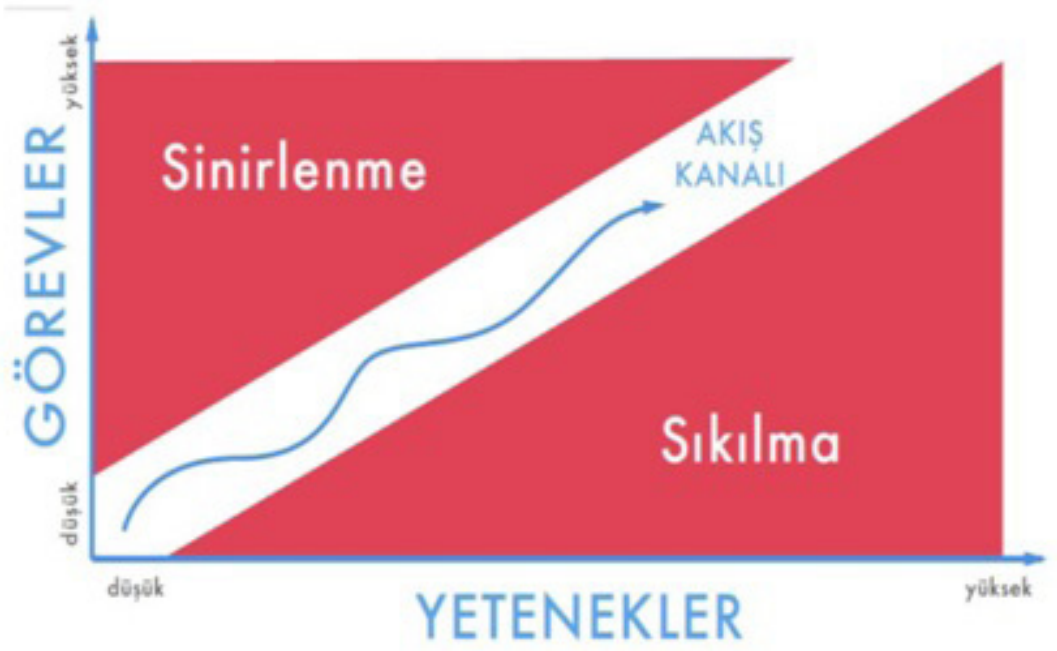

Şekil 11: Otonom ve Özerklik ${ }^{19}$

Csikszentmihalyi göre akış kuramında ototelik önemli bir yer tutmaktadır. Ototelik terimi öz anlamındaki oto ve hedef anlamındaki telos sözcüklerinden ortaya çıkmıştır. Kendi kendine yeten gelecekte bir fayda beklentisi olmadan tek ödülü kendisi olan aktivite anlamına gelir. Örnek vermek gerekirse, para kazanmak için borsa oynamak ototelik bir deneyim değildir; ama kişinin gelecekteki trendleri tahmin etme beceresini kanıtlamak için oynaması otetelik bir deneyim yaratmaktadır. Ototelik sayesinde sıkıntının yerini haz alır, çaresizlik bir kontrol hissine dönüşür ve psişik enerji dışsal amaçların hizmetine kaybol- 
mak yerine öz hissini güçlendirmek için çalışır. İnsan aynı şeyi uzun süre aynı seviyede yapmaktan haz almaz ya sıkılır yada hayal kırıklığına uğrar (Csikszentmihalyi 2020: 107-109).

\subsection{Oyuncu Türleri}

\section{“Oyun, insanoğlunun ilk kültürel alfabesidir.” Johan Huzinga}

Oyun düşüncesinin en önemli noktalarından birisi tüm oyuncuların aynı olmadığı, bir oyun tasarımı içerisinde genellikle farklı oranlarda farklı oyuncu türlerinin yer aldığıdır. Bu konu üzerine sıklıkla kullanılan sınıflandırma ise oyuncu türleri taksonomisidir. Bartlein dört oyuncu tipi bulunmaktadır. Oyuncu tiplerini bu dört ana başlıkta incelememize rağmen, aslında her oyuncu bu tiplerin hepsine belirli oranda sahiptir. Yani her oyuncu bir miktar başaran, bir miktar kâşif, bir miktar katil ve bir miktar sosyaldir. Bunun üzerine bir veya ikisi baskınlık oluşturur (Kunduracıoğlu 2018:24). Oyuncularınızı anlamanıza yardımcı olabilecek bir değerlendirme listesi, Richard Bartle'ın oyuncu türlerini anlamada yaptığı çalışmalar sonucunda oyuncu tiplerinde $\% 80$ sosyalizer, $\% 50$ kâşif \%40 başarı \%20 katiller olduğu gözlemlenmiştir (Zicherman - Cunningham 2011: 22-23).

1-Başaranlar (Achievers): Sadece hedefleri gerçekleştirmeye veya kazanmaya değil aynı zamanda iyi performans göstermeye odaklıdırlar. Ödülleri, amaçları gerçekleştirmeyi, görevi tamamlamayı ve lider cetvellerini seven oyuncu tipleridir. (Bozkurt- Kumtepe 2014: 150-151) Puan yükseltmek, deneyim kazanmak, rozet toplamak gibi öncelikleri vardır. Tek başına yapamayacağı görevler için veya rehberliğe ihtiyaç duyduğunda sosyalleşir (Kunduracioğlu, 2018:24). Bu tip tam bir görev adamıdır. Kendisi görevi başardığ1 müddetçe diğer oyuncuların da başarmasında sorun görmez (Yılmaz 2015: 111).

2-Sosyalleşenler (Socializers): Diğer oyuncularla etkileşime geçmeye odaklı oyuncu tipidir. İşbirliği ve takım çalışması gerektiren oyunları tercih ederler (Bozkurt ve Kumtepe, 2014: 150-151). Bu oyuncu tipi için oyun aslında sosyallik için bir araçtır. Amacı ne puan almak ne öldürmek ne de oyunu keşfetmektir. Önemli olan arkadaş ortamında güzel vakit geçirebilmektir. Sosyaller için kazanmak ya da kaybetmek önemsizdir. Seviye atlamak veya oyunda ilerlemek tamamen topluluk içinde yer edinebilme ve bir statü kazanma ihtiyacı olarak ortaya çıkar (Kunduracıoğlu 2018: 24). 
3-Kaşifler (Explorers): Oyun dünyasıyla etkileşime geçen, sırları çözmeye, bulmacalara yanıt bulmaya odaklı oyuncu türüdür. Oyun içerisinde genellikle yeni yollar ve yöntemler keşfetmeye çalışırlar.

4-Katiller (Killers): Genellikle diğer oyunculara karşı bir mücadele içerisindedirler ve başarılarını sergilemeyi severler. Kazanmak bu oyuncu tipi için önemlidir ve kazanmak için ne gerekiyorsa yapmaya odaklanırlar (Bozkurt ve Kumtepe, 2014: 150-151). Bu oyuncu tipi başkalarının kaybetmesini sağlamak, engellemek ve başka oyuncuları yenmek için oynar. Bu yüzden kaybedeni olmayan oyunlar ilgisini çekmez (Kunduracioğlu 2018: 24).

\subsection{Saps Ödüllendirme Teoremi}

“'Biriyle bir yll sohbet etmek yerine bir saat oyun oynayın daha iyi tanırsiniz." Plato

Dünyaca ünlü oyunlaştırma uzmanı Gabe Zichermann ödül çeşitlerini oyunlaştırma tasarımında dört ayrı aşamada incelemiştir. SAPS, (Status-Access-Power ve Stuff) baş harflerinin kısaltmasından oluşmaktadır (Zicherman - Cunnigham 2011: 10). Kullanıcılara maddi ödüller vererek elde tutmayı hedeflemektedir. Kullanıcıya ödül olarak, dışsal motivasyon unsurlarından olan, elle tutulabilir ve materyalist ödüller vererek, sistem dışında olanları hızlıca sistem içine çekmek için kullanılır (Vardarlıer -İnan 2017: 12).

1-Stuff (Eşya): Kullanıcıya ödül olarak elle tutulabilen, materyalist ve parayla takas edilebilir ya da edilemese de parayla başka yollarla alabileceği ödüller vermek. Örneğin bir rozet veya bir hediye çeki vermek.

2-Power (Güç): Oyuncuları güç ile ödüllendirmek, kullanıcının oyunun ya da sürecin içerisinde diğer oyuncular üzerinde kontrol sağlaması için bazı güçler, haklar verilmesi olarak tanımlanmıştır. Örneğin Foursquare-Swarm'ın eğer mayorsanız o mekanla ilgili fotoğrafları ve yorumları düzenleyebilme hakk1.

3-Access (Erişim): Erişim normal oyuncuların erişimine ve kullanımına kapalı olan daha çok sistemin sahibi ya da statü sahibi kişilerin erişebildiği bilgi, mekan ya da aletlerdir. Örneğin havalimanındaki VIP salonlarına giriş imkânı veya $\mathrm{CEO}$ ile bir öğle yemeği.

4-Status (Statü): Statü sistemdeki rollerden bazılarını kullanıcılara vererek sistemin bazı kısımlarını onların bu sıfatla yönetmelerini ve takibi ve kar- 
Ş1sında da ödüllendirilmesini kapsar. Örneğin Türk Hava yollarında Miles and Smiles kartlarının verilmesi (Yalçın 2016: 49-51).

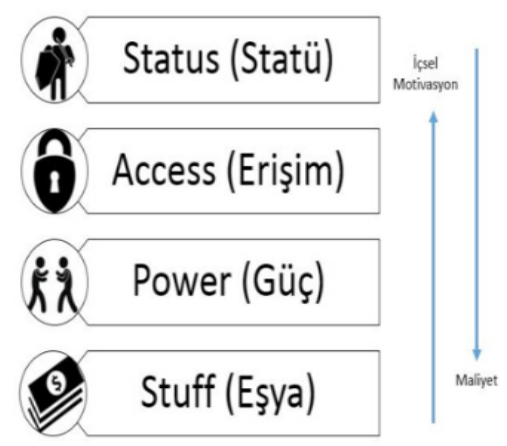

Şekil 12: SAPS Ödüllendirme Teorimi (Vardarlıer - İnan 2017: 12)

\subsection{Oyunlaştırma Etiği}

Etik sözcüğü Yunan dilinde karakter anlamına gelen"ethos" kelimesinden türemiştir. Etik, bireylerin toplumda ve birbirleriyle kurmuş oldukları ilişkiler sonucu ortaya çıkan bir kavramdır. ${ }^{20}$ Etik, insanın özgürlügünü çevreleyerek insanı yönetir. Aynı zamanda kamu yararı çerçevesinde kurumsal eylem ve işlemleri yönlendirip, toplumsal yararlılığı sağlar. Toplumsal kalkınmayı amaçlayan, ahlaki davranışlara rehberlik eden bir düşünce sistemidir (Usta 2010: 159). İyi, kötü, doğru ve yanlış gibi kavramları inceleyen, değerler ve standartlar sistemi olarak tanımlanan etiğin özünde doğru ve yanlış ölçütleri yatmaktadır (Pelit - Güçer 2006: 96). Pazarlama araştırmasındaki etik konular genellikle iki nedenden kaynaklanmaktadır. Birincisi; araştırmacılar araştırma esnasında kamuoyu ile sık sık ilişki kurma durumunda olup kamudan elde edilen bilginin duygusal ya da yanlış anlamda kullanılma riski ile karşı karşıya olunmasıdır. İkincisi ise; çoğu pazarlama araştırmasının ticari endişelerle gerçekleştiriliyor olmasıdır (Özdemir 2009: 123). Oyunlaştırma yönteminin, bireyleri istenilen davranışa yönlendirmede manipüle edici ve bağımlılık yaratıcı bir araç olarak kullanımına dair kaygılar pazarlama sektöründe kendini göstermektedir (Özay 2019: 30). Tarihsel süreç içerisinde yeniliğin getirdiği bilinmezlik sebebiyle endişelere ve korkulara neden olan birçok yeni teknoloji gibi oyunlaştırmanın da bireysel ve toplumsal ölçekteki etkileriyle ahlaki kaygilara sebebiyet vermektedir. Bu bağlamda etik ilkelerin belirlenmesi, hükümetler tarafından yasal düzenlemelerin yapılması, tasarımcı ve oyunlaştırmayı kullanan şirket yöneticilerinin 
bilinçlendirilmesi son derece önemli adımlar olduğunu söylemek mümkündür (Özkan - Taşkıran 2019: 23-24).

Lindstrom'un etik konusundaki görüşü; çekiç yanlış ellerde olursa insanın kafasına öldürücü darbeyi indirmek için kullanılabilir, oysa bu çekici yasaklamak bütün çekiçleri yasaklamay1 gerektirmez (Lindstrom 2016: 14). Csikszentmihaly görüşü; ateş hem isıtır hem de yakar, atom enerjisi elektrik de üretir dünyayı yok da edebilir. Enerji bir güçtür ama güç sadece bir araçtır. Uygulanış şekli hayatı daha zengin veya daha acılı bir hale getirebilir (Csikszentmihaly 2020: 110).

Journal of Business Ethics tarafindan yayınlanan Thorpe ve Roper'in"The Ethics of Gamification in a Marketing Context (Pazarlama Bağlamında Oyunlaştırma Etiği)" makalesinde, pazarlamadaki oyunlaştırmanın diğer pazarlama araçlarından ve oyunlaştırılmış ortamlardan önemli şekillerde farklı olduğunu savunmaktadır. Şirket ve hissedarları için kabul edilebilir olan şey, bir tüketici için kabul edilemez olabilir (Thorpe - Roper 2017: 6-7). Oyunlaştırmaya dair etik sorunlarında madalyonun diğeri bir yüzü bu tasarımların hangi amaçlarla kullanıldıklarıyla ilgilidir. Örneğin bir terörist grup kendilerine daha çok taraftar bulmak ve görüşlerini yaymak amaçlarıyla kullandıkları web sitesini, ziyaretçilerin video ve haberleri paylaşma, yorum yapma, tartışmalara katılma gibi eylemlerini artırmak için puan, liderlik tablosu, seviyeleri kullanarak başarılı bir şekilde oyunlaştırabilir (Özkan 2018: 64). Oyunlaştırma uygulamalarının etik sınırlar dâhilinde gerçekleşmesi amacıyla konuyla ilgili çözüm önerileri son yıllarda gittikçe tartışılmaktadır. Buradaki asıl problem, pazarlama sektöründe yer alan kural ve ilkelerinin oluşturulmasından ziyade, bu kural ve ilkelerin hayata geçirilmesinin zorluğudur. İşletmeler giderek artan rekabet ortamında bu gelişmeleri dikkate alarak etik ilkeler yönünde davranmaya her zamankinden daha çok önem vermelidir (Varinli - Çatı 2010: 504-505). Oyun danışmanı ve web geliştiricisi olan Andrzej Marczewski (2013) oyunlaştırmanın etik kurallarını oluşturmuştur. Bu kurallar; dürüstlük, bütünlük, açıklık, kalite ve saygıdır. ${ }^{21}$

\section{Oyunlaştırma Etik Kuralları}

\section{1-Dürüstlük}

Oyunlaştırma tasarımcıları hem kullanıcılara hem de müşterilere karşı dürüst olmalıdır.

Müşterilere oyunlaştırma ile neler yapılabileceğine dair gerçekçi 
beklentiler verilmelidir.

$\checkmark \quad$ Oyunlaştırma, kullanıcının diğer koşullar altında serbestçe vazgeçmeyeceği bilgileri dürüst olmayan bir şekilde toplamak için kullanılmamalıdır.

\section{2-Bütünlük}

$\checkmark \quad$ Oyunlaştırma, kabul edilen bölgesel sosyal uygulamaları, kişisel veya etik sınırları ve genel insan haklarını göz önünde bulundurmalı ve insanları onları kırmaya yönlendirmek için kullanılmamalıdır.

$\checkmark \quad$ Oyunlaştırma, yasa dişı faaliyetler için kullanılmamalıdır (kullanımının amaçlandığı ülke ve yerel yasalar tarafindan tanımlandığı şekilde).

$\checkmark \quad$ Oyunlaştırma, kullanıcıları, özellikle yaşlılar veya çocuklar gibi en saygıdeğer olanları ticari amaçlarla manipüle etmek için kullanılmamalıdır.

\section{3-Şeffaflık}

$\checkmark \quad$ Sistemin amaçlarının ne olduğu, hangi verilerin nasıl toplanacağ1na dair bilgiler bireylere ve kurumlara açıkça paylaşılmalıdır.

$\checkmark \quad$ Kişisel verileri asla uygun onay olmadan paylaşılmamalıdır.

$\checkmark \quad$ Bilgiye serbest erişim açık tutulmalıdır.

\section{4-Kalite}

$\checkmark \quad$ Oyunlaştırma uygulayıcıları her kullanıcı ve müşteri için daima mümkün olan en iyi hizmeti ve deneyimi sağlamalıdır.

\section{5-Saygı}

Oyunlaştırma şiddet, 1rkçılık, istismar, kadın düşmanlığı veya benzerlerini haklı kılan ifadeler yapmak için kullanılmamalıdır.

$\checkmark \quad$ Proje ve çalıştayların çevre üzerindeki etkisini ve sürdürülebilirliğini göz önünde bulundurun.

\subsection{Oyunlaştırma Uygulamaları}

"Hayat hızlı ve baş döndüren bir oyundur; hayat bir paraşütle atlamaktır, risk almak, düşmek ve yeniden kalkmaktır; dăgcılıktır, en yükseğe çıkmay istemek ve yapamadı̆̆ınızda kızgınlık ve tatminsizlik hissetmektir." Paulo Coelho.

Uzun yıllardır birçok alanda kullanılan oyunlaştırma kurguları artık ha- 
yatın dijitalleşmesi ile evrim geçirmiştir. Oyunlaştırma denildiğinde akla gelen çok başarılı uygulamalar şunlardır (Y1lmaz 2015: 47).

1-FourSquare-Swarm; kullanıcıların belirli mekân ve yerlerde giriş yaparak sanal puan ve ödül topladıkları yer tabanlı bir hizmet sağlayıcı uygulamadır. 2014 yılı itibariyle tüm dünyada 45 milyon kullanıcısı vardır ve günde yaklaşık beş milyon giriş yapılmaktadır. Özellikle puanlama, rozet sistemi ve lider tahtası bileşenlerini kullanmasıyla öne çıkan bir uygulamadır (Bozkurt - Kumtepe 2014: 152) Foursquare, insanların sosyal ağlar oluşturmasını ve konumlarını arkadaşlarıyla paylaşmasını sağlayan lokasyon ${ }^{22}$ tabanlı bir uygulamadır (Frith 2013: 248). Foursquare uygulaması, oyunlaştırmanın temel öğelerini kullanarak ziyaret edilen yerleri bildirmek, bu yerler hakkında yorum yapmak ve bu yorumların paylaşılması üzerinden hareket etmektedir. Belirli bir sıklıkla bir lokasyonda en fazla yer bildirimi yapan kullanıcı, o mekânın 'belediye başkanı' (mayor) rozetini kazanmakta ve bir bardak ücretsiz kahve gibi küçük hediyelerle ödüllendirilmektedir (Okmeydan 2018: 4758).

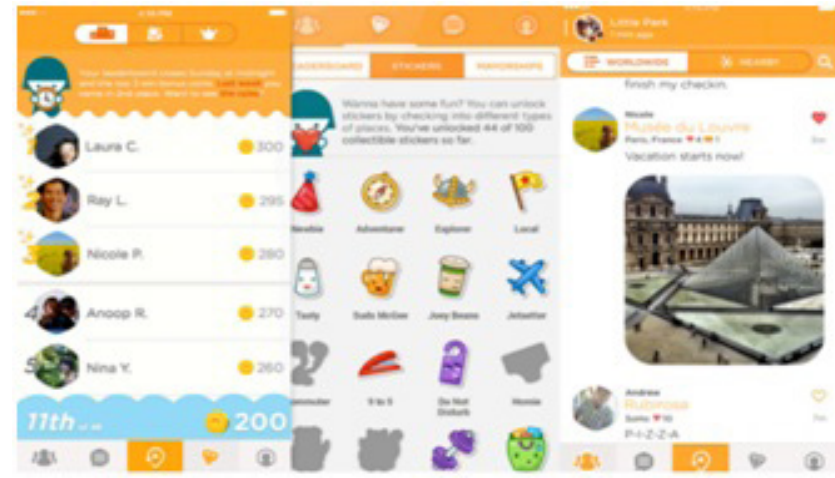

Şekil 13: Swarm Uygulaması (Kocaağa 2017: 30)

2-NikePlus/Nike+: ABD'nin önde gelen spor ayakkabı, giyim ve aksesuar tasarımcısı ve pazarlayıcısı olan Nike, Mayıs 2006 yılında Apple ile kurduğu ortaklık çerçevesinde Nike+ (NikePlus) platformunu başlattı. Bu sayede koşu yaparken müzik dinleyebilme yeniliği sayesinde pazarlama alanını genişleten Nike, aynı zamanda Apple tarafından üretilen özel bir giyilebilir teknolojik cihazın, belirli koşu ayakkabılarına entegre ederek kullanıcıların koşu faaliyetlerine ilişkin verilerin takip edilmesi ve her kullanıcının geldiği seviyele-

22- Lokasyon, İngilizce Location kelimesinden gelmektedir. İsim olarak "yer, konum, mevki, yerleştirme, yer belirleme" gibi anlamlara gelmektedir. 
rin paylaşılması sonucunda etkili bir oyunlaştırma tasarımı gerçekleştirmiştir (Okmeydan 2018: 4758-4759). Bu uygulama sayesinde, koşucular mobil bir yazılım sayesinde, koştukları mesafeyi, yazılımın sağladığı teknik GPS (Global Positioning System) altyapısı sayesinde tespit ederek kayıt etmekte ve toplam hız, harcanan kalori ve toplam koşu süresi bilgilerini mobil ara yüz üzerinden sisteme yüklemeleri sağlanmaktadır. Koşucular bu aşamadan sonra bu verileri kendi arkadaşları ve tanımadıkları insanlarla paylaşarak bir rekabet ortamı içine girmektedirler. Bu rekabet ortamında, koşucular, farklı kriterlerde birbirleriyle yarışabilme imkanına sahiptir. Rekabet ortamı içine giren koşucular, elde ettikleri başarılarla farklı başarı rozetleri kazanarak toplam rekabet listesinde sıralarını yükseltmeye çalışmaktadır (Bayraktar 2014: 59).

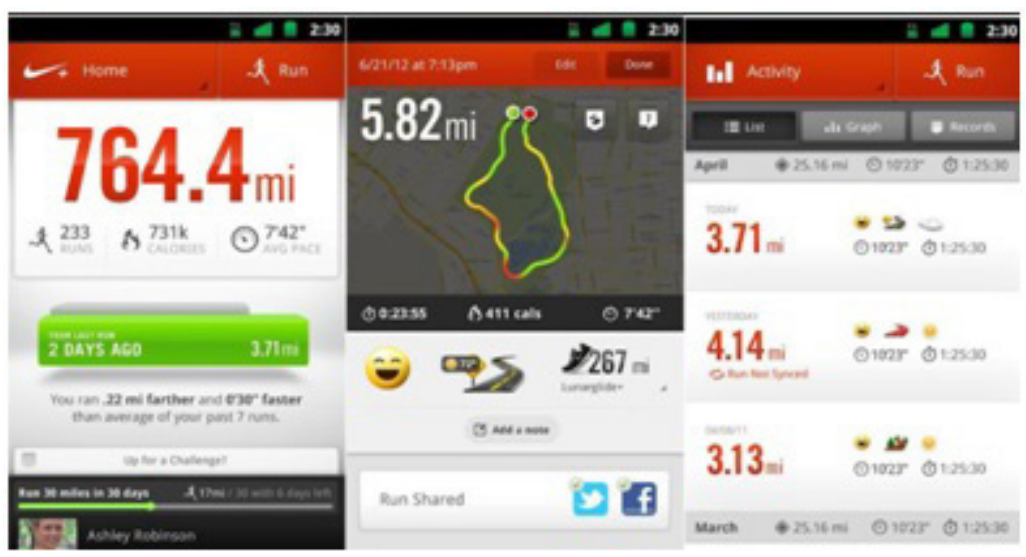

Şekil 14: NikePlus Uygulamas1 $1^{23}$

3-BiTaksi: Bitaksi oyunlaştırma uygulamasının amacı, yolcu taşıma hizmeti kalitesini artırmaktır. Performans puanına göre seviye atlayan kullanıcılar, kazandıkları altınlarla da aşağıdaki hediye sekmesinden bir ürünler alabilmektedir. ${ }^{24}$ BiTaksi olarak taksi arayan yolcularla, yolcu arayan taksileri bir araya getiren bir akıllı telefon uygulamasıdır. İster nakit ister kredi kartıyla ödeme işlemi gerçekleştirilmektedir. Üstelik işitme ve görme engelli yolcuların da rahat kullanması için dizayn edilmiştir. ${ }^{25}$

Sürücüler, bu uygulamadaki en üst seviye olan 'Elit Rozet Grubu'na dahil

23- (https://www.business2 community.com/strategy/gamification-basics-what-is-gamification-and-how-can-it-help-your-business-0267924)

24- (https://www.webtures.com.tr/blog/a-dan-z-ye-oyunlastirma)

25- (http://www.bitaksi.com/bitaksi-nedir) 
olmak için birbirleri ile yarışarak daha yüksek puan toplama gayreti içerisine girmekte, daha iyi hizmet vermek için iç ve diş ödüllerle daha kolay motive olmakta ve bu süreçte sürüş deneyimlerine eğlence unsurunu eklemektedir (Okmeydan 2018: 4761). Bu uygulamayla bulunduğunuz noktadan taksi çağrısında bulunuyorsunuz, size en yakın üye taksiler talip oluyorlar. Siz istediğiniz taksiyi seçiyorsunuz. Bununla kalmıyor. Akıllı telefon ve sosyal medyadan alışık olduğumuz puanlama sistemi burada da uygulanıyor. Yolcu taksiyi ve sürücüyü puanliyor, yorum yazabiliyor. Hatta taksi şöförü de yolcuyu puanlayabiliyor, yorum yazabiliyor, gerektiğinde şikâyet edebiliyor. ${ }^{26}$ Bi'Taksi Stratejik Planlama Grup Müdürü Altan Açıkgöz: Sisteme dahil edilen taksi sürücülerinin hem uygulamayı daha yoğun kullanmalarını sağlamak, hem de sürücü topluluğu içinde bir sinerji yaratarak adına oyunlaştırma senaryoları oluşturduklarını dile getirmiştir (Özay 2019: 34).
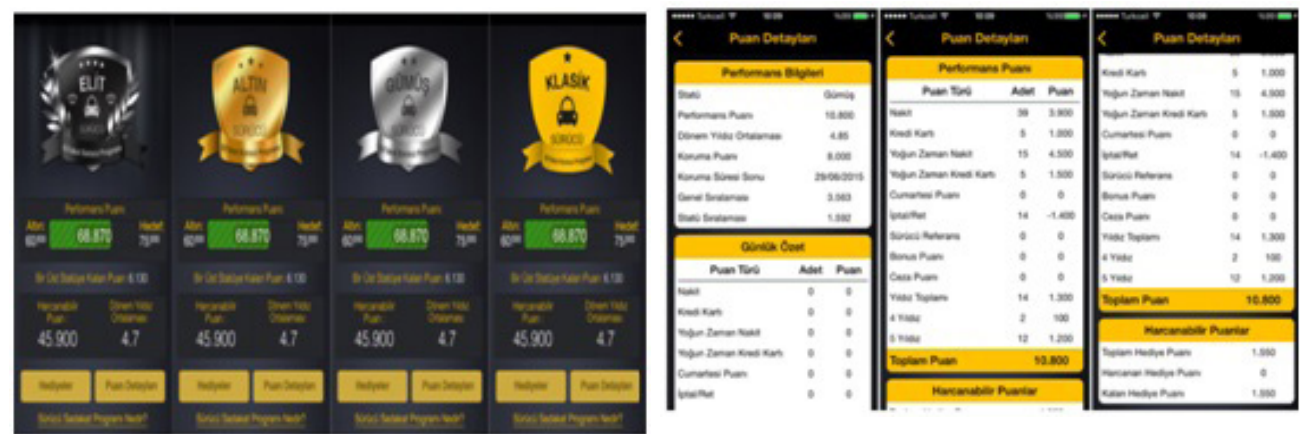

Şekil 15: BiTaksi Uygulamas $2^{27}$

4-Change Talk Childhood Obesity and Overweight: Amerikan Pediatri Akademisi (AAP) işbirliği ile gerçekleştirilen uygulama. Çocukluk çağı obezitesine yakalanan hastalar ve hasta yakınlarının daha etkili iletişim kurabilmelerine olanak sunmaktadır. Bu uygulama ile hastanın güdülenmesini artırmak, sağlık davranışlarında değişiklik yapmak amaçlanmaktadır. Uygulama, sanal pediatrist (sağlık çalışanı) ile çocukluk çağı obezitesi hastası ve annesi arasında kurgulanmıştır. Sanal hasta ve annenin davranışları pediatristin sorularına göre değişmektedir (Güler 2015: 94). Kullanıcıları sanal insanlarla rol oynama sohbetlerine dahil etmek için öğrenme bilimini, konuşma sanatını ve oyun teknolojisinin gücünü birleştirerek farklı yaklaşımları denemelerine, kişiselleştirilmiş geri bildirim almalarına ve benzer sohbetleri yönetme konusunda güven ve

26- (https://www.kariyer.net/ik-blog/oyun-artik-isin-bir-parcasi/)

27- (https://www.umityildirim.com/bitaksi-ve-oyunlastirma-uygulamalari) 
beceri kazanmalarına olanak tanıdığı görülmektedir. ${ }^{28}$
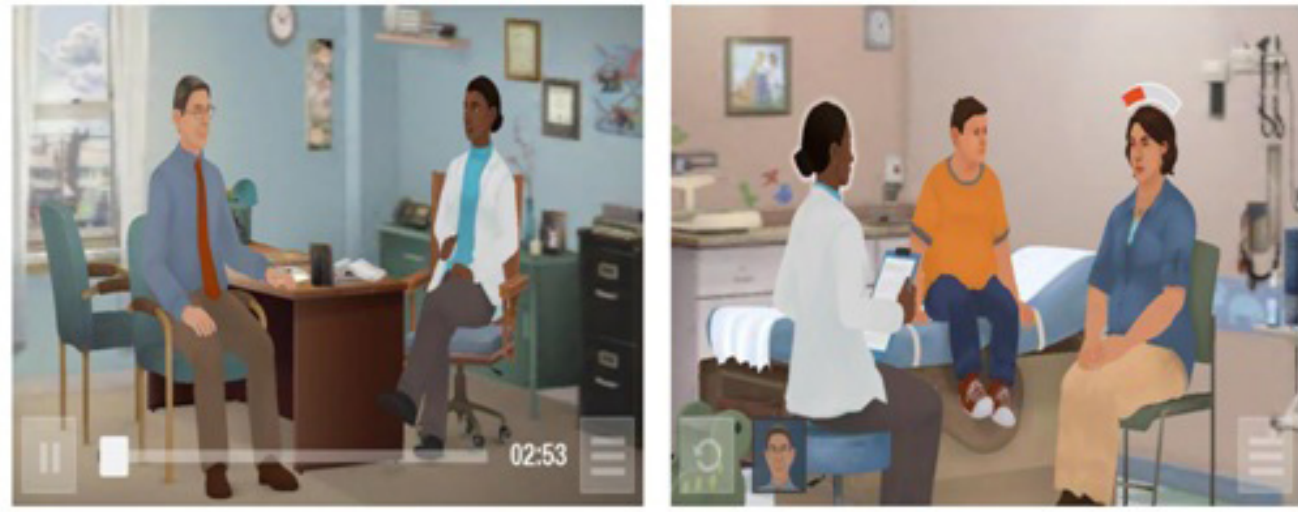

Şekil 16. Change Talk Uygulamas $1^{29}$

5-Vanarama: İngiltere merkezli ticari araç kiralama şirketi olan Vanarama, satış elemanlarının satış deneyimlerini oyunlaştıran ve motive edici bir program olan Vanarama League gerçekleştirmek için RMG isimli yazılım şirketi ile oyunlaştırma iş birliği yapmıştır. Satış temsilcileri, sisteme bir satış kaydettiğinde bir yazar kasa sesi duyuyor ve dev bir skor tablosu üzerinde çalışma arkadaşlarına kıyasla nasıl performans gösterdiklerini görebiliyorlar. Ayrıca bu skor tablosu ayın, haftanın ve yılın en iyi satış temsilcilerini de ön plana çıkartıyor. ${ }^{30} \mathrm{RMG}$ şirketi yapmış olduğu oyunlaştırma uygulaması sayesinde eğlenceli, yenilikçi, üretkenliği artırıcı ve yaratıcı, bir çalışma ortamı yaratmıştır.

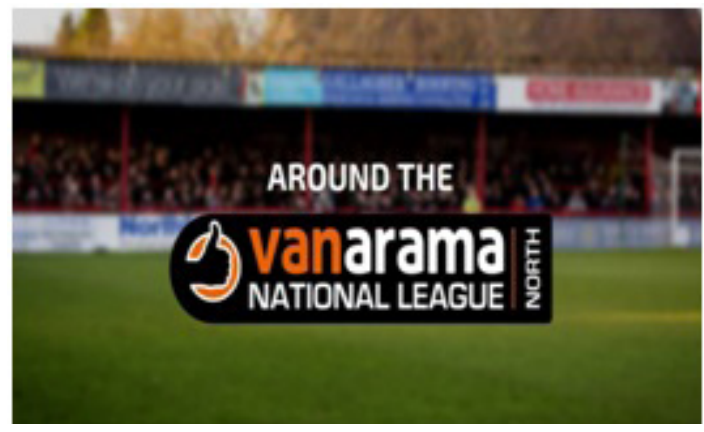

Şekil 17. Varanama Uygulamasi ${ }^{31}$

6-The Speed Camera Lottery: San Franciscolu oyun yapımcisı Kevin

28- (https://kognito.com/about)

29- (https://www.imedicalapps.com/2015/01/free-change-talk-app-teaches-doctors)

30- (https://pazarlamasyon.com/oyunlastirma-ile-verimliligi-artiran-4-sirket/)

31- (https://www.altrinchamfc.com/news/around-the-vanarama-national-league-north) 
Richardson tarafından 2010 yılında Eğlence Teorisi kapsamında Stockholmde sürücülerin hız limitlerine uyması için bir oyunlaştırma tasarladı. Sürücülerin adreslerine hız limitini aşan sürücülerin adreslerine anında ceza gönderilmekte, hız limitine uyan sürücülerin evlerine ise piyango bileti gönderilmektedir. Hız limitine uymayanlara kesilen para cezalarından elde edilen gelir, bu piyango ile hız limitine uyanlara dağıtılmaktadır. Bu sayede sürücülerin ortalama hızlarında yüzde 22'lik düşüş, gerçekleşmiştir. ${ }^{32}$ Bu aplikasyon o kadar etkili olmuştur ki 2011 yılının en iyi tasarlanmış oyunlaştırma uygulaması ödülünü almaya hak kazanmıştır (Yılmaz 2015: 43). Bu uygulama sayesinde Volkswagen'inin İsveç’teki payını ve satışlarını artırmaya devam etmesine yardımcı olmuştur. Ocak-Haziran 2010'da Volkswagen, pazar payını \%4 artışla \%12,9'a yükseltirken, satışları 2009 yılının ilk yarısına kıyasla \%3,9 artışla \%5,8'e yükseltmişstir. $^{33}$

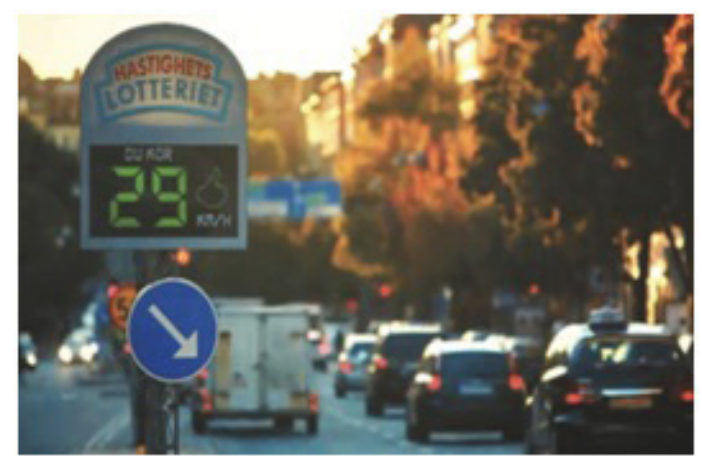

Şekil 18. Hız Kamerası Uygulamas ${ }^{34}$

\section{SONUÇ}

“Insan, oynadı̆̆ı müddetçe tam insandır.” Friedrich Schiller

21. yüzyılda küreselleşmenin etkisi ile birlikte, rekabetin yoğun olduğu iş hayatında eğlenerek çalışmanın önemi göz ardı edilemez bir hal almıştır. Oyunlar sayesinde işler daha eğlenceli ve akıcı şekle dönüşmüştür. Oyunlaştırma gücünü oyun dinamiklerinin insan beyninde yaratmış olduğu dopamin ve oksitosin kimyasallarının, mutluluk ve haz duygusunu açığa çıkarmasından almıştır. İşletmelerde motivasyon insan ilişkilerine yön veren, rekabet duygu-

32- (https://medicalfuturist.com/swedish-speed-camera-lottery-healthy-living/)

33- (https://theinspirationroom.com/daily/2011/volkswagen-speed-camera-lottery/)

34- (http://brandnewgametr.com/oyunlastirma-ne-degildir-2) 
sunu tetikleyen ve davranış değişikliği yaratmaktadır. Oyunlaştırma sayesinde işletmelerde oluşabilecek problemler ve stresli çalışma ortamı daha efektif bir şekilde yönetilebilmektedir. Teknoloji ve dijitalleşmenin toplumun birçok alanında etkili olduğu günümüzde yapay zekâ (artificial intelligence), artırılmış gerçeklik (augmented reality) ve sanal gerçeklik (virtual reality) teknolojileri oyunlaştırmanın daha interaktif bir şekilde uygulanabilir olmasını sağlamıştır.

Sonuç olarak pazarlama sektöründe yapılan çalışmalar, oyunlaştırmanın başarıya ulaşacağını açıkça göstermiştir. Günümüzde pazarlama sektörü için trilyonlarca para harcayan firmalar artık oyunlaştırma sayesinde çok daha düşük bütçeler ile büyük etkileşimler sağlayabilmekte. Oyunlaştırma kavramı eğitimden pazarlama stratejilerinin geliştirilmesine kadar birçok alanda uygulama alanı bulan başarılı yeni bir yaklaşımdır. Pazarlama sektöründe oyunlaştırma yöntemini uygulayan işletmelerin başarı göstermesi her şeyden önce etik ve insani değerlere sıkı sıkıya uymasına bağlıdır. Önümüzdeki zamanlarda işletmelerin, pazarlama stratejilerinde oyunlaştırma uygulamalarına daha çok yer vereceğini göreceğiz. 


\section{KAYNAKÇA}

ADANALI, Anıl - TELMEN, Nursel (2009), İş’te Oyun, İstanbul, Sistem Yayıncilik.

ALTUNTAŞ, Başar - KARAARSLAN, Mustafa Halid (2016), “Türkiye'deki Seçilmiş Pazarlama Vakalarının Oyunlaştırma Kavramı Çerçevesinde İncelenmesi”, Mehmet Akif Ersoy Üniversitesi Sosyal Bilimler Enstitüsü Dergisi, (8)17, 433-447.

ASLAN, Mecbure - DOĞAN, Selen (2020), "Dişsal Motivasyon, İçsel Motivasyon ve Performans Etkileşimine Kuramsal Bir Bakış", Süleyman Demirel Üniversitesi Vizyoner Dergisi 11, Say1: 26, 291-301.

AYDIN, Selin Ögel (2018), Oyunlaştırmanın Tüketici Beslenme Tercihleri Üzerine Etkisi, Eskişehir: Anadolu Üniversitesi Sosyal Bilimler Enstitüsü, (Yayımlanmamış Doktora Tezi).

AYTAŞ, Gıyasettin - UYSAL, Başak (2017), "Oyun Kavramı ve Sınıflandırmasına Yönelik Bir Değerlendirme”, MCBÜ Sosyal Bilimler Dergisi, (15)1, 675-690.

BAHÇECİ, Ferhat - UŞENGÜL, Leyla (2018), "Eğitim ve Öğretim Uygulamalarında Yeni Bir Yaklaşım: Oyunlaştırma”, Trakya Eğitim Dergisi, (8)4, 703-720.

BAŞAL, Handan Asude (2007), “Geçmiş Yıllarda Türkiye'de Çocuklar Tarafından Oynanan Çocuk Oyunları”, Eğitim Fakültesi Dergisi, 20(2), 243266.

BAİTUROVA1, Kyial - ALAGÖZ, Selda Başaran (2017), "Müşteri Sadakatini Etkileyen Bir Araç Olarak Oyunlaştırma”, KMÜ Sosyal ve Ekonomik Araştırmalar Dergisi, 19(33), 134-143.

BAYRAKTAR, Özgür (2014), Bir İletişim Modeli Olarak Oyunlaştır$m a$, İstanbul: Maltepe Üniversitesi Sosyal Bilimler Enstitüsü, (Yayımlanmamış Yüksek Lisans Tezi).

BİCAL, Adil (2016), Oyunlaştırmada Oyun Elemanlarının Kullanımı: Adidas Micoach, Khan Academy, Superbetter ve Swarm Uygulamalarının Örnek Olay Yöntemi İle Incelenmesine Yönelik Keşifsel Bir Çalışma, Eskişehir: Anadolu Üniversitesi Sosyal Bilimler Enstitüsü, (Yayımlanmamış Yüksek Lisans Tezi). 
BOZBAY, Heval (2013), “Geçmişten Günümüze Aşık Oyunları”. Uluslararası Kıbrı Üniversitesi Folklor-Edebiyat Kültür Dergisi, (19)73, 147-161.

BOZKURT, Aras - KUMTEPE, Evrim Genç (2014), “Oyunlaştırma, Oyun Felsefesi ve Eğitim: Gamification”, Mersin Üniversitesi XVI. Akademik Bilişim Konferansı Bildirileri, 147-156.

CSİKSZENTMİHALYİ, Mihaly (2020), Akış Mutluluk Bilimi, (çev.) Barış Satılmış, Ankara, Buzdağı Yayınevi.

ÇELİK, Gonca- TAHİROĞLU, Ayşegül - AVCI, Ayşe (2008), "Ergenlik Döneminde Beynin Yapısal ve Nörokimyasal Değişimi”, Klinik Psikiyatri Dergisi, (23)1, 42-47.

COOK, Whitney (2013), "Five Reasons You Can't Ignore Gamification", Chief Learning Officer, 12(5), 46-55.

DANDOY, Jermiah (1996). "Astragali, The Ubiquitous Gaming Pieces" Expedition 38(I), 51-58.

DETERDİNG, Sebastian- DİXON, Dan, vd. (2011), "From Game Design Elements To Gamefulness: Defining Gamification, Mind Trek". 15. Uluslararası Akademik Konferansı Bildirileri, 9-15.

DICHEV, Christo - DICHEVA, Darina, vd. (2014), "From Gamification To Gameful Design And Gameful Experience In Learning”, Cybernetics And Information Technologies, 14(4), 80-100.

ELKİND, David (2011), Oyunun Gücü, (çev.) Demet Erol Öngez, Ankara, İmge Kitapevi.

ERGÜN, Mustafa (1980), “Oyun ve Oyuncak Üzerine-I”. Mili Eğitim, (1/1), 102-119.

ERÜMİT, Semra Fiş - KARAKUŞ, Türkan (2015), "Eğitim Ortamlarında Yeni Bir Yaklaşım: Oyunlaştırma, Eğitim Teknolojileri Okumaları”, Eğitim Teknolojileri Okumaları.

FRITH, Jordan (2013), “Turning Life İnto A Game: Foursquare, Gamification And Personal Mobility, Mobile Media - Communication”, 1(2), 248-262.

GÖKKAYA, Zeynep - DENIZ, Levent (2014), “Üniversite Öğrencilerinin Bilgisayar Oyunu Oynama Alışkanlıkları ve Oyun Tercihleri: Marmara Üniversitesi Örneği”, Akademik Sosyal Araştırmalar Dergisi, 2(6), 58-73. 
GÜLER, Can - GÜLER, Emel (2015), “Çevrimiçi Öğrenme Ortamlarında Oyunlaştırma: Rozet Kullanımı”, Ĕğitim ve Öğretim Araştırmaları Dergisi, (4)3, 125-130.

GÜLER, Emel (2015), "Mobil Sağlık Hizmetlerinde Oyunlaştırma”, Açıköğretim Uygulamaları ve Araştırmaları Dergisi, 1(2), 82-101

HİZINGA, Johan (2015), Homo Ludens, (çev.) Mehmet Ali Kılıçbay, İstanbul. Ayrıntı Yayınları.

KAPP, Karl M. (2012), The Gamification Of Learning And Instruction: Game-Based Methods And Strategies For Training And Education, John Wiley $\&$ Sons.

KOCADERE, Selay Arkün - SAMUR, Yavuz (2016), Oyundan Oyunlaştırma, Eğitim ve Teknoloji Okumaları.

KOCAAĞA, Bayram (2017), Oyunlaştırma İlkeleri Temelinde Bir Çevrimiçi Oyunlaştırma Platformunun Sınıf Içi Uygulamalara Yönelik Olarak Geliştirilmesi, İstanbul: Yıldız Teknik Üniversitesi Fen Bilimleri Enstitüsü, (Yayımlanmamış Yüksek Lisans Tezi).

KUNDURACIOĞLU, İsmail (2018), Oyunlaştırma Kavramı Üzerine Analiz Çalışması, Balıkesir: Balıkesir Üniversitesi Fen Bilimleri Enstitüsü, (Yayımlanmamış Yüksek Lisans Tezi).

KUMAR, Janaki Mythily - HERGER, Mario (2013), Gamification at Work: Designing Engaging Business Software, The Interaction Design Foundation

LINDSTROM, Martin (2016), Buy.ology, (çev.) Ümit Şensoy, İstanbul, Optimist Yayınları

LOVETT, E. M. Longworth Dames, D. F. de 'Hoste Ranking, C. Violet Turner, E. Linder - E. C. Sykes. (1901). "The Ancient and Modern Game of Astragals", Folklore, 12(3), 280-293.

MCGONIGAL, Jane (2011), Reality Is Broken, London: Jonathan Cape.

MEŞE, Can - DURSUN, Özcan Özgür (2018), “Oyunlaştırma Bileşenlerinin Duygu, İlgi ve Çevrimiçi Katılıma Etkisi”, Ĕgitim ve Bilim, (43)196, 67-95. 
MİHELAČ, Lorena - KAPŠ, Roman vd. (2017), Mesleki Ĕgitimde Oyunlaştırma El Kitabı, Ljubljana Ulusal ve Üniversite Kütüphanesi.

NEGRUŞA, Adina Letiţia - TOADER, Valentin vd. (2015), "Exploring Gamification Techniques And Applications For Sustainable Tourism”, Sustainability, (7), 11160-11189.

OKMEYDAN, Selin Bitirim (2018), Pazarlama Oyuna Geldi: Pazarlamada Oyunlaştırma Yaklaşımı ve Örnekleri , Journal of Social And Humanities Sciences Research, (5)31, 4750-4768.

ÖZAY, Hazar Utku (2019), Oyunlaştırmanın Marka Sadakati Üzerindeki Etkisinde Ăgızdan A ğıza İletişimin Moderatör Rolü, İstanbul: Marmara Üniversitesi Sosyal Bilimler Enstitüsü, (Yayımlanmamış Yüksek Lisans Tezi).

ÖZDAŞLI, K. - AKMAN, H. (2012). “ İçsel ve Dışsal Motivasyonda Cinsiyet ve Örgütsel Statü Farklılaşması: Türk Telekomünikasyon A.Ş. Çalışanları Üzerinde Bir Araştırma”, Süleyman Demirel Üniversitesi Vizyoner Dergisi. (4)7. 73-81.

ÖZDEMIR, Erkan (2009), "Pazarlama Araştırmasında Etik Karar Alma", Ankara Üniversitesi SBF Dergisi, 64(02), 119-144.

ÖZER, Hasan Hüseyin (2016), Eğitimde Oyunlaştırılmış Öğrenme Ortamlarının Öğrenci Başarısına ve Uygulamaya Yönelik Etkisi: Classdojo Örne$\breve{g} i$, Lefkoşe: Yakın Doğu Üniversitesi Eğitim Bilimleri Enstitüsü, (Yayımlanmamış Yüksek Lisans Tezi).

ÖZKARA, B. Y. - ÖZMEN, M. (2016). “Akış Deneyimine İlişkin Kavramsal Bir Model Önerisi”. Eskişehir Osmangazi Üniversitesi IIIBF Dergisi, (11)3. 71-100.

ÖZKAN, Çiğgem - TAŞKIRAN, Hatun Boztepe (2019), "Kurum İçi İletişim Stratejileri Bağlamında Oyunlaştırma Kullanımı: Bankacılık Sektörü Üzerine Bir Araştırma", International Journal of Cultural and Social Studies, (1)5, 15-47.

ÖZKAN, Çiğgem (2018), Kurum İçi İletişim Stratejileri Bağlamında Oyunlaştırma Kullanımı: Bankacılık Sektörü Üzerine Bir Araştırma, İstanbul: İstanbul Üniversitesi Sosyal Bilimler Enstitüsü, (Yayımlanmamış Yüksek Lisans Tezi). 
PELİT, Elbeyi - GÜÇER, Evren (2006), “Öğretmen Adaylarının Öğretmenlik Mesleğiyle İlgili Etik Olmayan Davranışlara ve Öğretmenleri Etik Dışı Davranışa Yönelten Faktörlere İlişkin Algılamaları", Ticaret ve Turizm Eğitim Fakültesi Dergisi, (2), 95-119.

PROCOPİE, Roxana - BUMBAC, Robert vd. (2015), “The Game Of Innovation, Is Gamification A New Trendsetter?" The Amfiteatru Economic Journal, 17 (Special No. 9), 1142-1155.

PİNK, Daniel H. (2017), Drive, (çev.) Levent Göktem, İstanbul, MediaCat

ROBSON, Karen - PLANGGER, Kirk, vd. (2015), "Is It All A Game? Understanding The Principles of Gamification", Business Horizons, (58), 411420.

SAKALLIOĞLU, Baram- EROL, Volkan - AKGÜN, Bekir Tevfik (2014)," Oyun Nedir ve Oyun Türlerinin Tanımlanmasinda Sosyal Oyunların Yeri”, Mersin Üniversitesi 14. Akademik Bilişim Konferansı Bildirileri, 117123.

SELEN, Ufuk (2016), Çalışanların İç ve Dış Motivasyon Tekniklerine Bakış Açılarının Değerlendirilmesi; Yerel Yönetim Örnĕgi, Tekirdağ: Namık Kemal Üniversitesi Fen Bilimleri Enstitüsü, (Yayımlanmamış Doktora Tezi).

SEVER, Serdar ve BİCAL, Adil (2018), “Oyunlaştırmada Oyun Elemanlarının Kullanımı: Adidas Micoach, Khan Academy, Superbetter ve Swarm Uygulamalarının Örnek Olay Yöntemi ile İncelenmesi”, Erciyes İletişim Dergisi, (5)3, 216-236.

SEZGİN, Sezan (2016), “İnsan ve Oyun: Oyunların Dünü, Bugünü, Yar1nı”, 15. Uluslararası Eğitim Araştırmaları Kongresi.

SEZGIN, Sezan- BOZKURT, Aras vd. (2018), “Oyunlaştırma, Eğitim ve Kuramsal Yaklaşımlar: Öğrenme Süreçlerinde Motivasyon, Adanmışlık ve Sürdürülebilirlik", Mehmet Akif Ersoy Üniversitesi Eğitim Fakültesi Dergisi, 2018, (45), 169-189.

ŞAHIN, Murat - SAMUR, Yavuz (2017), "Dijital Çağda Bir Öğretim Yöntemi: Oyunlaştırma”, Ege Eğitim Teknolojileri Dergisi, (1)1, 1-27.

TEZTEL, Gülden (2016), "Psikolojide Akış Kuramı ve Müzik İcrası Bağlamında Değerlendirilmesi”, Konnservatoryum, (3)2, 1-17. 
THORPE, Andrea - ROPER, Stephen (2017), "The Ethics of Gamification in a Marketing Context", Journal of Business Ethics, 155(9), 1-27.

TUNGA, Yeliz - İNCEOĞLU, Mustafa Murat (2016), “Oyun Tasarımı, 3”, Uluslararası Eğitimde Yeni Yönelimler Konferans1, 267-279.

USTA, Aydın (2010), "Kamu Görevlisinin Etik Amaç ve Ahlaki Yükümlülügüne Yönelik Bir Değerlendirme”, Türk İdare Dergisi, (468), 159-181.

ÜNGÜREN, Engin (2015), "Beynin Nöroanatomik ve Nörokimsayal Yapısının Kişilik ve Davranış Üzerindeki Etkisi”, Uluslararası Alanya İşletme Fakültesi Dergisi, (7)1, 193-219.

VARDARLIER, Pelin - INAN, Koray (2017), “Gamification Model Proposal For The Improvements Of Sales Personnel Performance", İş 'te Davranış Dergisi, (2)1, 8-18.

VARİNLİ, İnci - ÇATI, Kahraman (2010), Güncel Pazarlama Yaklaşımlarında Seçmeler, Ankara, Detay Yayıncılık,

YALÇIN, Gönül (2016), "Sosyal Medyada Oyunlaştırma Uygulamalarının Kullanım Motivasyonuna Etkileri”, İstanbul: İstanbul Bilgi Üniversitesi Sosyal Bilimler Enstitüsü, (Yayımlanmamış Yüksek Lisans Tezi).

YEŞİLTAŞ, Meryem Derya - TÜRK, Murat (2017), “İş Akış Kuramı ve Beş Faktör Kişilik Modeli İlişkisi Üzerine Bir Araştırma”, Osmaniye Korkut Ata Üniversitesi İktisadi ve İdari Bilimler Fakültesi Dergisi, (1)2, 117-128.

YILMAZ, Ercan Altuğ (2015), Oyunlaştırma, İstanbul, Abaküs Yayınları.

ZİCHERMANN, Gabe - CUNNIGHAM, Christopher (2011), Gamification by Design Implementing Game Mechanics in Web and Mobile Apps, O'Reilly Media, E-book.

https://www.altrinchamfc.com/news/around-the-vanarama-national-league-north (Erişim Tarihi: 10.01.2020)

https://arkeofili.com/ur-kraliyet-oyunu-yeniden-canlandirildi (Erişim Tarihi: 10.01 .2020 )

https://bilimdili.com/toplum/yasam/karacay-malkar-turklerinde-asikoyunu/ (Erişim Tarihi: 10.01.2020)

http://brandnewgametr.com/oyunlastirma-ne-degildir-2 (Erişim Tarihi: 04.03.2020) 
https://brandnewgametr.com/game-ve-play-arasindaki-fark/ (Erişim Tarihi: 04.03.2020)

http://brandnewgametr.com/Oyunlastirma-Kilavuzu.pdf (Erişim Tarihi: 05.03.2020)

http://www.bitaksi.com/bitaksi-nedir (Erişim Tarihi: 14.04.2020)

https://www.business2community.com/strategy/gamification-basics-what-is-gamification-and-how-can-it-help-your-business-0267924 (Erişim Tarihi: 20.05.2020)

https://ethics.gamified.uk/ (Erişim Tarihi: 20.05.2020)

https://www.imedicalapps.com/2015/01/free-change-talk-app-teaches-doctors (Erişim Tarihi: 14.02.2020)

https://www.kariyer.net/ik-blog/oyun-artik-isin-bir-parcasi/ (Erişim Tarihi: 20.02.2020)

https://kognito.com/about (Erişim Tarihi: 03.02.2020)

https://medicalfuturist.com/swedish-speed-camera-lottery-healthy-living/ (Erişim Tarihi: 23.03.2020)

https://www.oyunlastirma.co/makale/turk-sirketlerinin-oyunlastirma-yolculugu (Erişim Tarihi: 01.03.2020)

https://pazarlamasyon.com/oyunlastirma-ile-verimliligi-artiran-4-sirket/ (Erişim Tarihi: 10.05.2020)

https://www.slideshare.net/ercanaltug/gamex-akar-oyunlastirma-ornekleri (Erişim Tarihi: 11.05.2020)

https://slideplayer.biz.tr/slide/8845307/ (Erişim Tarihi: 09.05.2020)

https://tr.wikipedia.org/wiki/Senet_(oyun)\#/media/File:Maler_der_Grabkammer_der_Nefertari_003.jpg (Erişim Tarihi: 08.03.2020)

https://theinspirationroom.com/daily/2011/volkswagen-speed-camera-lottery/ (Erişim Tarihi: 10.03.2020)

https://www.temelaksoy.com/pazarlama-yapmak-davranis-mimarligi-yapmaktir/ (Erişim Tarihi: 15.03.2020)

https://www.umityildirim.com/bitaksi-ve-oyunlastirma-uygulamalari (Erişim Tarihi: 10.04.2020) 
https://yilmazturkben07.wordpress.com/cocukta-oyun-gelisimi/oyunun-dogusu-ve-tarihcesi/ (Erişim Tarihi: 20.03.2020)

https://www.youtube.com/watch?v=gneeHbdt9Rw (Oyunlaştırarak Hayatla Aşık Atıyorum! | 2017 | Ercan Altuğ Yılmaz | TED Konuşması) (Erişim Tarihi: 10.05 .2020$)$

https://www.webtures.com.tr/blog/a-dan-z-ye-oyunlastirma (Erişim Tarihi: 26.05.2020) 
Oya ŞAKI AYDIN

DIJITAL KÜLTÜRÜN "OYNANAN" MASALLARI: BRAWL STARS OYUNUNUN GREIMAS'IN EYLEYENSEL ÖRNEKÇESINE GÖRE INCELENMESi

Aybike SERTTAŞ - Dorukan ÇELIK

TÜRK SINEMASINDA AILE KURUMUNUN TEMSILI VE DÖNÜŞÜMÜ

Erman AKILLIBASS - Kutalmış Emre CEYLAN

OYUNLAŞTIRMANIN PAZARLAMADAKI GÜCÜ

Ferdi AKBAS

TURiZMDE BÜTÜNLEŞTiRMENIN SALIHLi (MANISA) ÖZELINDE DEĞERLENDIRILMESi

Onur SEMIZ

DEMOKRAT PARTI DÖNEMI 19 MAYIS KUTLAMALARININ AYIN TARIHI MECMUASI'NA YANSIMASI (1950-1955)

Hüseyin GÜNARSLAN

MYANMAR MÜSLÜMANLARININ TARIHI

Elif İBȘİROĞLU BAYRAM

BILGI TOPLUMU SÜRECINDE ŞiiRIN DÖNÜŞÜMÜ

Başak BURAK

ADANA ULU CAMI MIHRABI ÜZERINE BIR DEĞERLENDIRME

Resul KÖSE

SOSYAL HIZMET TARIHI BAĞLAMINDA MILASLI ISMAIL HAKKI BEY'IN ALKOL BAĞIMLILIĞI VE KURTULMANIN ÇARELERINE DAIR GÖRÜŞLERI 